\title{
The Physician and the Other: Images of the Charlatan in Medieval Islam
}

\author{
PETER E. PORMANN
}

Summary: Physicians have always tried to demarcate themselves from the Other, whom they labeled as a "charlatan." During the medieval period, Arabic physicians such as al-Rāzī attacked charlatans in their theoretical and deontological writings, and, like their Greek predecessors, called on the authorities to stamp out malpractice. Their advice was partly heeded, as can be seen from manuals on market inspection (hisba). Physicians accused their colleagues of quackery based on charges of incompetence or deceit, which must be seen partly as an attempt to protect themselves from potential competitors. Certain groups of society, including women and Jews, were an especially convenient target. Moreover, charlatans also appear in nonmedical texts such as al-Ğaubarî’s manual on tricksters and al-Harīin's Assemblies or Maqāmāt. These accounts suggest that, despite the calls of the medical elite to exclude quacks from the marketplace, the latter were able to attract customers and continue to practice.

KEYWORDS: medieval Islamic medicine, medical deontology, quackery, antiSemitism, female practitioners, market inspection (hisba)

Where there are physicians, there are charlatans, quacks, empirics. Medical practitioners have always tried to distinguish themselves from the Other, from those whom they deem unprofessional, whether the latter

This article is based on a paper read at the symposium "The Art of Medicine: ImageMaking and Communication," held at Yale University on 15-17 April 2004 and sponsored by the Beinecke Rare Book and Manuscript Library, the Harvey Cushing/John Hay Whitney Medical Library, the Whitney Humanities Center, and the Yale Center for British Art; I would like to thank the organizers, and particularly Peter M. Jones, for inviting me and giving me the opportunity to discuss my ideas in such a stimulating environment. The original impetus for broaching this subject stemmed from conversations with Emilie Savage-Smith when I was working with her on a book entitled Medieval Islamic Medicine (to appear late in 2006 in the series New Islamic Surveys, Edinburgh University Press); she generously shared her material with me, and I am greatly indebted to her for reading and criticizing different versions of this article. Finally, I would like to record my gratitude to Tony Lévy, with whom I conferred about some variant Hebrew readings, as well as to the two anonymous referees. All translations, unless otherwise attributed, are my own. 
has good or bad intentions. Already in classical antiquity, Hippocratic texts such as the famous Oath or the deontological treatises such as Law and Decorum attempted to define a group of proper physicians, subject to specific rules, who practiced medicine in a legitimate way. ${ }^{1}$ Such texts excluded those who did not conform to a specific set of regulations that governed not only the way in which medicine was employed, but also the outer appearance of the doctor, his manner of speaking, and his general character. These prescriptive texts make plain that there was a huge variety of practitioners in the marketplace, many of whom did not subscribe to the rules laid out by the Hippocratics or other authorities. The attitudes contained in these writings are not unlike those present in the medical profession nowadays, which is deeply suspicious of alternative practices and techniques going beyond the methods of orthodox medicine. Traditional Chinese or Ayurvedic recipes, for instance, are derided for their lack of active ingredients and their purported inefficiency. In the absence of hard "scientific" proof, their distributors are at best seen as ignorant in believing their cures to have anything beyond the benefit of a placebo; at worst, they are deemed to be crooks, marketing products that they know to be inefficient. In Britain, as in most other countries, there are professional bodies such as the National Institute for Clinical Excellence $^{2}$ who decide which remedies work and which do not; they determine which drugs can be prescribed "on the NHS" (National Health Service) and for which ones the patient has to dip into his or her own pocket. Furthermore, the General Medical Council in the United Kingdom-engaged, according to its own Web site, in "protecting patients, guiding doctors"3-determines who is a legitimate physician; it has the power to exclude practitioners from the medical profession and to restrict their capacity to provide health care.

In the present contribution I propose to explore images of the charlatan during the medieval Islamic period, focusing on the heyday of medical theory and practice in the Islamic world, roughly defined here as

1. Some of these deontological treatises are conveniently collected in William H. S. Jones, ed., Hippocrates, vol. 2, Loeb Classical Library, no. 148 (Cambridge: Harvard University Press, 1926). They are generally thought to be quite late, but it is not necessary to discuss their respective dates here; see ibid., pp. xxxiii-li, 257-61, 269-77. On the general topic of distinguishing between physician and charlatan in the Hippocratic Corpus (and especially in On the Sacred Disease), see Évelyne Samama, "Médecin ou charlatan? Comment reconnaître un bon soignant dans le monde grec," in Mires, physiciens, barbiers et charlatans: Les marges de la médecine de l'Antiquité au XVI e siécle, ed. Franck Collard and Évelyne Samama (Langres: D. Guéniot, 2004), pp. 9-32.

2. http://www.nice.org.uk/ (accessed 29 December 2004).

3. http://www.gmc-uk.org/ (accessed 29 December 2004). 
the ninth to thirteenth centuries CE. ${ }^{4}$ I shall investigate how physicians belonging to the medical elite demarcated themselves from other people in the medical marketplace by painting a negative picture of the others' practice, thereby enhancing their own standing. In addition to these physicians, I shall also look at nonmedical writers who represent quacks and mountebanks in a slightly different light.

I concentrate here on images, perceptions, and depictions of the Other in written works, including theoretical and deontological medical treatises, manuals of market inspection, and other literature. From the following investigation, a number of trends will emerge about how the charlatan is construed as the Other who falls outside the bounds of one's own legitimized identity. This said, it is important to note that discussions in theoretical and prescriptive literature do not necessarily reflect the historical situation at any given time. My approach is somewhat similar to that employed by Nadia M. El Cheikh in her recent book Byzantium Viewed by the Arabs. She investigates how the Byzantines as the Other are perceived and depicted by Arab authors from a variety of backgrounds and periods, saying:

History's postmodern anxiety over the status and meaning of reality is here circumvented by an awareness that this effort is directed toward disclosing a discourse - that we are trying to uncover a representation, not reality. ${ }^{5}$

The emphasis here is similarly on analyzing textual representations of charlatans, rather than on providing an accurate historical account of their lives and activities.

The illusiveness of historical reality aside, we encounter the temptation to make sweeping generalizations about Arabic authors' images of the charlatan. Within the vast world of medieval Islam, where the scientific and medical elite mainly used the Arabic language, ideas traveled fast and were discussed on the shores of the Guadalquivir and the Ganges alike. ${ }^{6}$ However, the fact that the same texts circulated at different geographical extremes of the Islamic realm does not mean that the same

4. All dates, unless otherwise specified, refer to the Common Era (CE).

5. Nadia M. El Cheikh, Byzantium Viewed by the Arabs, Harvard Middle Eastern Monographs, no. 36 (Cambridge: Harvard Unversity Press, 2004), p. 12.

6. In the following, I shall talk about Arabic medicine, physicians, treatises, and so on, as opposed to Islamic ones. This I do for the sole reason that the texts considered here, and the medical tradition to which they belong, are Arabic in the sense that they use the Arabic language as their vehicle. However, the authors are neither all Arabs, nor all Muslims, so that my using the term "Arabic" is somewhat unsatisfactory. For a more detailed discussion of this question, see Peter E. Pormann, The Oriental Tradition of Paul of Aegina's "Pragmateia," Studies in Ancient Medicine, vol. 29 (Leiden: Brill, 2004), pp. 1-2. 
perceptions prevailed. The focus, here, is on the Arabic heartland: Iraq, Syria, and, to a lesser extent, Egypt. Even within this territorial delimitation, it is impossible to give a comprehensive overview of alternative medical practice over the course of some five hundred years; rather, I shall elucidate certain trends, tendencies, and techniques employed by physicians to define themselves and delineate their medical activity in order to preserve their market share and promote their profession.

Before turning to the heart of the matter, it is useful to situate the present inquiry within the framework of other scholarly approaches to quackery and charlatanism, often discussed (as here) in connection with efforts to regulate the medical profession. ${ }^{7}$ First, it would be a mistake to suggest that the medieval medicine on either shore of the Mediterranean is much the same as modern medical practice. It would be similarly erroneous to claim that there was any homogeneity of practice across geographic regions in the Middle Ages. Nonetheless, as initially stated, certain concerns about defining what it means to be a physician, and who should be allowed to practice, existed then as they do now. In the Latin West, for example, the authorities in Valencia and Paris went to considerable lengths in order to license and regulate medical practice, as Luis García- Ballester and his coauthors, and Danielle Jacquart, have demonstrated. ${ }^{8}$ David Gentilcore has argued in a recent study that, in early modern northern Italy, the authorities went so far as to license "charlatans." ${ }^{9}$ Although medieval Islamic practitioners worried about fraudsters and charlatans, the historical situation between 800 and 1300 in the Levant and in Iraq is at variance with that in the Latin West: no comprehensive system such as those in place in Valencia or northern Italy during

7. There is a recent conference bundle on the subject, containing articles about the definition of charlatans in the classical world, during the late Latin Middle Ages, and the early modern period in Europe and Mexico: Franck Collard and Évelyne Samama, eds., Mires, physiciens, barbiers et charlatans: Les marges de la médecine ... (see n. 1). Unfortunately, I was able to see it only when proofing the present article; however, since it does not contain any contributions about the time period and area discussed here, my argument remains relatively unaffected by this publication.

8. See Luis García-Ballester, Michael R. McVaugh, and Agustín Rubio-Vela, Medical Licensing and Learning in Fourteenth-Century Valencia, Transactions of the American Philosophical Society, vol. 79.6 (Philadelphia: American Philosophical Society, 1989); Danielle Jacquart, La médecine médiévale dans le cadre parisien, xive -xve siècles (Paris: Fayard, 1998), pp. 303-10, where she discusses the efforts of the Paris faculty to restrict medical practice, allowing only people licensed by it to work as medical practitioners.

9. David Gentilcore, “'Tutti i modi che adoprano i ceretani per far bezzi': Towards a Database of Italian Charlatans," Ludica, 2000, 5-6: 201-15. 
the late Middle Ages existed in the Islamic world throughout this period-or in Europe before 1200, for that matter. We find evidence of a general concern among elite physicians to set themselves apart from their underqualified would-be colleagues; however, these concerns as presented here do not demonstrate the existence of a formal administrative framework, a point that will be discussed in greater detail in section III below.

Second, this study should not be seen as akin to the social histories of alternative practitioners provided by scholars such as Gentilcore or GarcíaBallester et al., who exploit a rich body of archival material pertinent to their subjects. For the period discussed here, there are no public archives listing, for example, those granted or denied licenses to practice medicine. Gentilcore puts names to different "charlatans" who really existed, analyzing where they came from and in what localities they exercised their profession; the information in his database of "charlatans" in sixteenth-to-eighteenth-century Italy is culled from records of Protomedicato tribunals, institutions that could grant or revoke permission to engage in medical activities. The source material employed here, however, consists of works by physicians and littérateurs, not records kept by clerks in public office. Of course, the descriptions contained in the texts considered here can certainly tell us something about the historical situation on the ground, but the social history of alternative practitioners in the Islamic world remains largely to be written-something that I do not attempt to do here.

Third, we must briefly consider the problem of defining a charlatan, and here, too, my approach is different from Gentilcore's. His Protomedicato tribunals actually licensed "charlatans" - that is to say, people belonging to alternative medical and paramedical professions. Thus Gentilcore's "charlatans" constitute a specific group of people mentioned in a defined corpus of documents, which allows him to make statements such as the following: "In Florence one hundred and fourteen charlatans even matriculated into the city's Guild of physicians and apothecaries between 1592 and 1620." 10 In the area and time under scrutiny here, there were no guilds of physicians; and had they existed, charlatans in the way I propose to use the term would not have been admitted. I do not investigate charlatans as a well-defined group within the society, but rather as a concept: a person becomes a charlatan in the eye of the beholder. Roy Porter famously wrote about charlatans in eighteenth-century England: "Everybody felt happy in execrating the quack, because, everybody could 
agree, the quack was someone else. Nobody ever called himself a quack."11 Porter's conception is very much in the spirit of my own use of the term, yet it is necessary to add a few precisions to the definition of charlatanism as it will be explored in this study.

In the Oxford English Dictionary, a charlatan is defined as "an empiric who pretends to possess wonderful secrets, esp. in the healing art; an empiric or impostor in medicine, a quack."12 The term "charlatan" came into the English language via French and is ultimately derived from the Italian ciarlare, meaning "to chatter, prattle, babble"; a charlatan is therefore somebody who praises his goods by talking loudly and publicly about them. A synonym for charlatan is "quack," an abbreviated form of "quacksalver," probably originally designating someone who "quacks" or shouts about his "salves" or ointments. The use of the word "empiric" in the definition of charlatan just quoted is extremely revealing, because it first designated someone who relied on experiment and experience in order to ascertain what was correct. It is partly because of the contempt in which Galen held "empirics," meaning medical practitioners who based their art on observation and experiment alone (as opposed to the rationalists and methodists), that "empiric" came to mean "an untrained practitioner in physic or surgery; a quack." ${ }^{13}$ These three terms illustrate the two important semantic elements used to qualify the Other, the dishonest or unprofessional medic: On the one hand, charlatans are quacks who shout about remedies that, in the eyes of the medical establishment, are useless; they use treacherous tricks to sell them to the gullible customer. On the other hand, charlatans are empirics who lack knowledge of theoretical medicine and are therefore deemed to be incompetent. Charlatanry is thus suspended between the two poles of trickery and incompetence. It is in this sense that it will be understood in the following when investigating how one group of people, physicians belonging to the medical elite, endeavored to exclude the other from their profession and attempted to prevent them from practicing medicine in any form or shape.

Let us finally consider another aspect of charlatanism: intent. The experts of yesteryear may seem to have practiced medicine in a completely ineffective manner, thus looking like ignoramuses to their succes-

11. Roy Porter, Quacks: Fakers and Charlatans in English Medicine (Stroud: Tempus, 2000), p. 15. See also William F. Helfand, Quack, Quack, Quack: The Sellers of Nostrums in Prints, Posters, Ephemera, and Books (New York: Grolier Club, 2002), p. 1.

12. The Oxford English Dictionary, 2nd ed., ed. John Simpson and Edmund Weiner (Oxford: Oxford University Press, 1989).

13. Ibid. 
sors. Conversely, remedies used by quacks of the past may prove to be effective according to modern drug-lore. Therefore, because standards change and shift over time, some scholars insist on the intent as the major defining feature of the charlatan; only people who deliberately deceive their customers are charlatans, irrespective of whether their treatments work or not. ${ }^{14}$ But it is difficult to look into people's minds, and therefore hard to ascertain whether or not a particular individual believed in the effectiveness of his or her practices, nor whether he or she was dishonest. As stated before, my focus is not so much on specific historical realities, but rather on images: how is the Other, the unprofessional, depicted and denigrated with the aim to exclude him or herand women were often the target of vicious attacks-from the marketplace? However, we shall see shortly that intent as a definining feature of quackery was not first proposed by modern scholars, but was already present in medieval times.

\section{Greek Models}

In order to demarcate oneself from the construed Other, one generally has recourse to a set of criteria. For some organizations, race, religion, sex, and social status serve to distinguish between "them" and "us"- as, for instance, in the case of some gentlemen's clubs on either side of the Atlantic, which traditionally accepted only white non-Jewish men belonging to high society. For medical associations, such as the General Medical Council mentioned at the beginning of this article, membership is contingent on a different set of criteria: physicians are required to assimilate a body of knowledge - a canon, so to speak-and they must also adhere to a specific ethical code; those who know this canon and comply with the rules are doctors, and others are not. In each case, a set of criteria is employed to create a group to the exclusion of others.

The different physicians who will be discussed in the following all have recourse to the idea of a canon of medical knowledge that a true physician needs to possess. This canon consists largely of Greek and Greek-based theoretical medical literature; in fact, Arabic medical writers often referred to a glorious Greek past (not infrequently more imagined than real) when forming their own medical traditions and

14. See, for instance, the definition in Émile A. Berthomier, Charlatanisme et médecine illégale (Paris: Ollier-Henry, 1910), p. 17: "En somme, nous définissons le charlatanisme médical, le fait, par une personne quelconque, munie ou non d'un diplôme de médecin, d'indiquer, dans un but intéressé, un remède comme efficace, alors que cette personne connaît la fausseté de ses indications." 
institutions. ${ }^{15}$ Therefore, a useful starting point for the investigation of how charlatans are depicted in Arabic medieval sources is to look at how Arab authors envisaged Greek attitudes toward quackery. What image do Arab physicians have of the Greek conception of charlatans? In order to answer this question, we shall look at accounts of two incidents in the life of Galen, who was the most accomplished practitioner and the most excellent physician in the eyes of many medieval doctors. In the first incident, he reveals the quackery of a mountebank in the market, while in the second, he himself resorts to tricking a patient.

Al-Qifțī (d. 1248) and Ibn Abī Ușaibía (d. 1270), two important medical historians, both relate the same anecdote from Galen's life, citing one of his works:

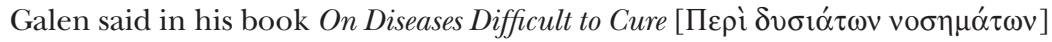
that he was passing through the city of Rome and came across a man around whom a circle of ignorant people [safi $h \mathrm{~s}]$ had formed. The man was saying to them: "I am one of the inhabitants of Aleppo. I have encountered Galen, and he taught me all his sciences. This is a remedy that helps against worms in the teeth." This wicked man [habīt $]$ had [previously] prepared a ball [bunduq] made out of tar and cotton. He placed it onto amber and fumigated the mouth of the patient who believed that he suffered from worms in his teeth. The patient had to close his eyes. Once he had closed them, this man slipped a worm into his mouth, which he had at hand in a box. Then he extracted it from the mouth of the patient suffering from tooth [ache]. After he had done this, the fools threw the things they had to him [i.e., gave him their money]. He even did more than this: he used venesection in places other than the joints. He [Galen] continues: "When I saw this, I showed my face to the people and said: 'I am Galen, and this is a fool [safī $h]$.' I warned them against him, and appealed to the ruler for assistance against him, so that the ruler had him whipped. Because of this I wrote a book about așhāb al-hiyal ["tricksters" or "methodists"]."

15. Hippocrates, for instance, is said to have been "the first to have invented the

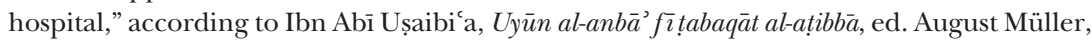
2 vols. (Cairo and Königsberg, 1884), 1: 27, line 1.

16. Ibid., 2: 81-82, line 8; al-Qifțī, Tả rihn al-Hukamä', ed. Julius Lippert (Leipzig: Dieterichsche Verlagsbuchhandlung, 1903), p. 124, lines 9-19. This passage has been translated into German by Max Meyerhof, "Autobiographische Bruchstücke Galens aus arabischen Quellen," Sudhoffs Archiv für die Geschichte der Medizin, 1929, 22: 72-86, on pp. 82-83. See also Manfred Ullmann, Die Medizin im Islam, Handbuch der Orientalistik 1, Suppl. 6.1 (Leiden: Brill, 1970), p. 57; Manfred Ullmann, Das arabische Nomen generis, Abhandlungen der Akademie der Wissenschaften in Göttingen, Philologisch-Historische Klasse, 3rd ser., no. 176 (Göttingen: Vandenhoeck \& Ruprecht, 1989), pp. 63-64, no. 85; Fuat Sezgin, Geschichte des Arabischen Schrifttums, 12 vols. (vols. 1-9, Leiden: Brill, 1967-84), 3: 129-30, no. 112. The title of Galen's work, așhāb al-hiyal, given here is problematic in two 
Since Galen's treatise On Diseases Difficult to Cure is unfortunately not extant in Greek, this being the most substantial fragment of the Arabic translation, we cannot ascertain the accuracy of the quotation. Nevertheless, from this account we can gain a clear picture of how, according to Arabic sources, Galen defined, and reacted to, a charlatan. First, it is important to notice that, at least according to the description given, the mountebank tricks his patient by removing something, in this case a worm, which he himself has surreptitiously placed there: he deliberately deceives his audience with an intent to defraud them of their money. Second, the quack is portrayed not only as dishonest, but also as incompetent, since he cups people at the wrong places. Third, he attempts to obtain the respect and trust of the onlookers by claiming that Galen taught him; Galen thus manifestly becomes a source of legitimization, lending authority to the practitioner. Fourth, Galen appeals to the authorities to stamp out medical malpractice and regulate practitioners.

These four elements-fraudulent intent, incompetence, legitimacy derived from Greek authorities, and calls to the authorities to control the medical marketplace-are important constituents of medieval Arabic attitudes toward charlatans. We shall return to the last three aspects, but first let me further illustrate the importance of fraudulent intent in defining a quack by looking at a second incident involving Galen.

senses. First, the Arabic așhāa al-hiyal is ambiguous. It literally means "those using ḥila," hìla denoting both "method" and "trick"; it is therefore a technical term for "methodists" ( $\mu \varepsilon \theta$ o $\delta$ เкоí)—i.e., physicians like Soranus who followed the "method"—as opposed to

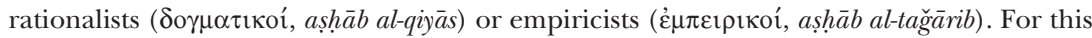
usage, see, for instance, the Arabic translation of Galen's On the Sects for Beginners: Kitāb Ğālīnūs fĩ firaq al-țibb li-l-muta'allimīn, ed. Muḥammad Salīm Sālim (Cairo: al-Hai'a alMișrìya al-āmma li-l-kitāb, 1977), passim; Peter E. Pormann, "The Alexandrian Summary (Jawāmi $\left.{ }^{c}\right)$ of Galen's On the Sects for Beginners: Commentary or Abridgment?" in Peter Adamson et al., Philosophy, Science and Exegesis in Greek, Arabic and Latin Commentaries, Supplement 83 to Bulletin of the Institute of Classical Studies, 2 vols. (London: Institute for Classical Studies, 2004), 2: 11-32. However, it can also just mean "trickster," "fraudster," as Meyerhof (ibid., p. 83 n. 2) understood it, translating it as "Betrüger, Kniffemacher" because of the context. Second, it is not entirely clear to which Galenic treatise al-Qifți and Ibn Abī

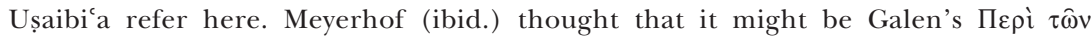
$\dot{\alpha} v \alpha \gamma \gamma v \omega \sigma \kappa o ́ v \tau \omega v \lambda \alpha \dot{\alpha} \theta \rho \alpha$ Ëv (About Those Reading Silently/Surreptitiously, One [Book]), a work that is entirely lost but is mentioned in Galen's [On My Own Books]: De libris propriis, ed. Karl G. Kühn, Claudii Galeni Opera Omnia, 20 vols. (Leipzig, 1821-33), 19: 5, line 20 (henceforth cited in the form Kühn, 19.5). Meyerhof assumes that the Greek title should be understood as meaning "About those who surreptitiously read [out books by Galen as if they were their own]"; this surmise would stretch the meaning of the Greek title substantially, and therefore belongs to the realm of speculation. 
In a chapter entitled "Anecdotes about Physicians and Some of Their Ruses [ $F \bar{\imath}$ nawādir al-atibb $\bar{a}$ ']" contained in 'Alī ibn Rabban al-Tabarī's Paradise of Wisdom [Firdaus al-hikma], completed in 850, the author tells the story of how Galen tricked a patient into believing that he had vomited a snake. While, in the case of the first incident, Ibn Abī Ușaibi ${ }^{\mathrm{c}} \mathrm{a}$ and al-Qifți acknowledge their source, a Galenic treatise, this second incident is related by al-Țabari without any indication of whence he took it. Therefore, it may well be apocryphal; nevertheless, it reveals an important point about Arabic perceptions of Galen. This is the anecdote:

Concerning their ruses [hiyal] and skillfulness, we [sc., al-Tabarī] learned the following: A man woke up thinking that a snake had entered his throat. Apprehension and distress seized him. Galen came to him, examined him, felt his stomach, and informed him that nothing had entered his stomach or his mouth. However, the patient did not accept Galen's opinion. When the latter saw that he did not accept it, being in turmoil, he [Galen] went out, asked for a snake, put it into a bag, came back and said: "I brought you an emetic." Galen gave the patient something to drink and ordered him to vomit after he had his eyes blindfolded, lest he see the snake coming out. He threw the snake into a metal basin, and said to him: "You are saved now, for the snake has come out of your belly." When the patient saw the snake, he recovered immediately. ${ }^{17}$

Here, it is Galen who tricks the patient. The difference between Galen's fraud and that of the charlatan in the first story is, of course, the intention with which the patient is deceived: Galen was seeking to cure the patient by freeing him from his delusional anxiety, whereas the charlatan just wanted to make a quick buck and did not intend to treat the patient effectively. Arabic authors were aware of this tension between deception for the right or for the wrong reasons, as another anecdote makes plain.

In one of Galen's genuine works, On the Affected Parts, which survives in Greek and was translated into English, Galen is similarly deceitful: he tricked his companion Glauco as well as the patient into believing that he

17. 'Alī ibn Rabban al-Ṭabarī, Firdaus al-hikma, ed. Muhammad Z. Siddiqi (Berlin: Sonnendruckerei, 1928; repr. Frankfurt am Main: Institut für Geschichte der arabischislamischen Wissenschaften, 1996), maqālā 2, bāb 5 (pp. 537, line 22, to 538, line 5). There is another version of this account in al-Ruhāwī, The Conduct of the Physician: Adab al-tabīb, ed. Fuat Sezgin (Frankfurt: Institut für Geschichte der Arabisch-Islamischen Wissenschaften, 1985), in the chapter on charlatans (i. 18; p. 209, lines 10-16); a translation is given in Martin Levey, Medical Ethics of Medieval Islam, with Special Reference to al-Ruhāwī's "Practical Ethics of the Physician," Transactions of the American Philosophical Society, n.s., vol. 57.3 (Philadelphia: American Philosophical Society, 1967), p. 90 (this book was reviewed in Göttingische Gelehrte Anzeigen, 1968, 220: 215-27, by J. Ch. Bürgel, who is quite critical of Levey's work). 
had diagnosed a condition from only feeling the pulse, while in reality he surmised the ailment from having seen the excrements of the patient in a chamberpot. ${ }^{18}$ In a short treatise on charlatans extant only in Hebrew, the famous physician al-Rāzī (d. 925), known in the Latin West as Rhasis, defends Galen's conduct, insisting that Galen has the welfare of the patient at heart: by giving greater credibility to his diagnostic skills through this sophisticated stratagem, he inspires confidence in the patient and helps him to recover. ${ }^{19}$ Charlatans, on the other hand, pursue only their own interests. It is therefore not the act of deception itself that is reprehensible, according to al-Tabarī or al-Rāzì , but the intent with which it is employed. One might remark that through this shady display of his ability to promote himself as an able and competent physician, Galen was at least partly pursuing his own interest, and not that of the patient-but this is not an idea expressed by either Arabic author; they do not challenge their famous colleague's motives.

Whatever the reason for this critical blind spot regarding Galen's deceptions - and, in general, al-Rāzì was not averse to voicing his disagreement with this great medical authority ${ }^{20}$ - Arabic authors see in Galen a physician who clearly understands what a charlatan is, believing that his or her activity should be curtailed. These images are further developed by Arabic physicians, as we shall see next.

\section{Deontology}

An area of medical literature in which physicians discuss quackery is medical deontology. Defining correct medical practice often involves a description of incorrect ones as well. Two medieval Arabic authors whose deontological works survive dealt in particular with charlatans; they

18. Galen, On the Affected Parts (De locis affectis), bk. 5 (Kühn, 8.361-6); Rudolph E. Siegel, trans., Galen on the Affected Parts (Basel: Karger, 1976), pp. 161-63.

19. The treatise is preserved in Munich, Bayerische Staatsbibliothek, MS hebr. 43 (henceforth MS Mh43) and Munich MS hebr. 280 (henceforth MS Mh280). The present passage is found in MS Mh43, fols. 98b, 10 lines from the bottom-99b, line 4; MS Mh280, fol. $50 \mathrm{a}, 10$ lines from the bottom-b, last line. (Folio numbers are followed by "a" for recto and " $b$ " for verso, and by the line numbers.) See Moritz Steinschneider, "Wissenschaft und Charlatanerie unter den Arabern im neunten Jahrhundert," Virchows Archiv, 1866, 36: 570_ 86; 37: 560-65; reprinted in Beiträge zur Geschichte der arabisch-islamischen Medizin, 3 vols. (Frankfurt: Institut für Geschichte der arabisch-islamischen Wissenschaften, 1987), 2: 39 61.

20. Al-Rāzì wrote, for instance, a work entitled Doubts about Galen: Šukūk 'alā Ǧàtīnūs, ed. Mahdī Muḥaqqiq (Tehran: Ma'had al-dirāsāt al-islāmīya, Ǧāmi'at Ṭihrān and Al-Ma 'had al‘ālī al-`ālamī li-l-fikr wa-l-ḥaḍāra al-islāmīya, 1993). 
devoted a special section and a specific treatise, respectively, to the topic, thereby providing a clear image of quackery. The first is the otherwise unknown physician Ishạāq ibn 'Alī al-Ruhāwī, who wrote a deontological treatise entitled Adab al-tabìb (Ethics of the Physician) in the second half of the ninth century. ${ }^{21}$ In it, he prescribes a certain conduct, bedside manner, and general behavior for the physician. Two chapters of particular interest to us here detail how to examine physicians, and warn against charlatans. ${ }^{22}$ In the latter, al-Ruhāwī extols his own profession, the art of medicine, and says that it incites people to envy, because it is so highly esteemed:

Since the art of medicine is the profession most able to bestow benefit upon man; since those belonging to it [ahluhā], who truly [bi-l-haqīqati] follow its methods, are considered by people to be in a noble and elevated class, and revered and esteemed; and since this art is confined to specific people, it is therefore attacked, for it is not possible for all those who wish to, to enter it. But since access to it is wide open to all those who seek $i^{23}$-while people naturally desire to obtain the sublime classes, honor, and respect, and since there is no profession higher than the art of medicine-people who do not belong to it [ $\dot{g}$ air ahliha $]$ seek it out because they are jealous of them [sc., those belonging to it]. Because they do not attain the true science [haqiqqatahā], and so do not reach excellence and an elevated station, owing to their poor

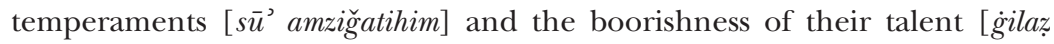
qarä'ihihim], they resort to tricking people with different kinds of quackery $\left[\mathrm{had}^{\mathrm{c}}\right]$ and ... [dahtama], which they conceal with the clothes and garb that they display, pretending through the way they speak, and in many other ways, to be similar to those who truly belong to the art. . . .

In short: their aim is to carry out activities that outwardly resemble sound medical practice, in order to convince people and to demonstrate to them their skillfulness in the art, while [just] making money. ${ }^{24}$

Al-Ruhāwī paints a clear picture of "them" and "us": he belongs to those who "truly [bi-l-haquqati]" follow the medical art; he is instantly

21. Fuat Sezgin produced a facsimile of the unique manuscript, Selimiye Library of Edirne, MS 1658: see n. 17 above.

22. Al-Ruhāwī, Conduct of the Physician (n. 17), chaps. i. 16, "On Examining Physicians," and i. 18, "On Warning against the Deceit $\left[\right.$ had $\left.^{c}\right]$ of Quacks [muhtālūn] Who Call Themselves Physicians, and the Difference between Their Deceit and Medical Methods [hiyal tibbīya]."

23. This statement could be seen as a contradiction to the previous sentence; however, this is not the case. Al-Ruhāwī means that true medicine is limited to the happy few, but it is easy to call oneself a doctor, even without any skills.

24. Al-Ruhāwī, Conduct of the Physician (n. 17), pp. 205, 5-13; 206, 3 lines from the bottom-last line; Levey, Medical Ethics (n. 17), pp. 88-89. This is mostly my own translation, that by Levey being more of a paraphrase. 
recognizable because of his dress and the way he talks; and his is the most noble profession, admired by all. Others who aspire to be physicians are, according to him, inspired by envy and greed. He eagerly dismisses them as charlatans and tricksters, and warns his potential patients against them. Two features of the charlatan are particularly salient in this description. First, al-Ruhāwī portrays them as incapable of becoming physicians: their natural disposition, their temperament, prevents them from joining this narrowly restricted class. Second, they are motivated not only by greed, but by jealousy; they yearn to be physicians, but, unable to obtain the necessary qualifications, they try to trick their way into it. In emphasizing jealousy and trickery, al-Ruhāwī extols himself and his colleagues, and insists on the gulf between "them" and "us." He also expresses his concern that charlatans imitate the customs and clothes of true physicians. Physicians are defined by the way they speak, dress, and behave: outer appearance serves to distinguish them from others; when outsiders do not respect this distinction, the legitimate members are themselves threatened.

Al-Rāzī, the second author, was, like al-Ruhāwī, concerned about the success of charlatans. In his Kitāb al-Manșūrī, the ninth book of which was widely known in the Latin Middle Ages and the Renaissance under the title Liber nonus or Nonus Almansoris, ${ }^{25}$ al-Rāzī included a chapter against quacks. This diatribe, first translated into English by J. Freind from the Latin version, gained some notoriety among scholars and has often been quoted.$^{26}$ It is basically a long catalog of tricks used by empirics, such as pretending to cure epilepsy through a cruciform incision of the head, faking the extraction of a snake from the nose, pretending to remove worms from the ears or the teeth while actually putting them there in the first place, and so on.

According to the Arabic bio-bibliographical tradition, al-Rāzì even composed a treatise with the programmatic title Epistle on the Reason Why the Ignorant Physicians, the Common People, and the Women in the Cities Are More Successful than Men of Learning in Treating Certain Diseases, and the

25. Ullmann, Medizin (n. 16), p. 132.

26. John Freind, The History of Physick, 4th ed., 2 vols. (London, 1750), 2: 65-69; William A. Greenhill, A Treatise on the Small-pox and Measles (London, 1848), pp. 80-82; Francis Adams, The Seven Books of Paulus Agineta, 3 vols. (London, 1844-47), 2: 245-46; Albert Z. Iskandar, "A Study of ar-Rāz̄̄'s Medical Writings, with Selected Texts and English Translations," 2 vols. (D.Phil. thesis, University of Oxford, 1959), 1: 385-87; Gary Leiser, "Medical Education in Islamic Lands from the Seventh to the Fourteenth Century," J. Hist. Med. Eं Allied Sci., 1983, 38:48-75, on pp. 66-67; Emilie Savage-Smith, "Medicine," in Encyclopedia of the History of Arabic Science, ed. Roshdi Rashed, 3 vols. (London: Routledge, 1996), 3: 90362, on pp. 937-38. 
Physician's Excuse for This (Risāla fì l-'illati llat̄̄ min ăglihā șāra yanğahu

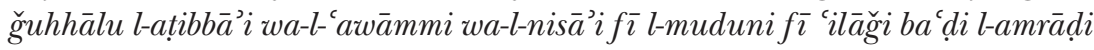

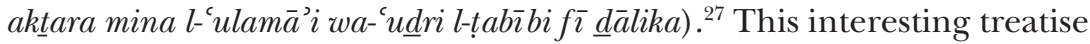
appears to be lost in Arabic; however, another work by al-Rāzī dealing with a related subject and called Treatise on the Causes Why Most People Turn Away from Excellent Physicians toward the Worst Ones (Maqāla fì l-asbābi l-mumīlati li-qulūbi aktari l-nāsi ' an afādili l-ațibba’i ilā ahsa’ihim) survives in a Hebrew translation. At the end of the previous section, I discussed a passage from this treatise in which al-Rāzī justifies Galen's use of deception when diagnosing a patient. However, al-Rāzī attributes the success of undeserving empirics to their misleading patients to believe that they can infer things about them from, for instance, urine, while in reality relying on other hints. This is illustrated in the following episode:

A great and learned physician in Cairo had a young pupil. A woman came to him with a vessel filled with urine. The young man went down to see who knocked on the door and to know who was at the gate. He found her and asked her to show him the urine. After he inspected it, he said: "The urine is that of a Christian; yesterday, he ate lentils, and he lives in such and such a neighborhood." She answered that all this was true, paid him, and left. The physician saw this from the window and heard what was said. When the pupil came back upstairs, he [the physician] inquired: "You said this and that to the woman. Now tell me truly how you knew what I myself could not have known." He began to beat him with whips until he confessed and replied: "I said that he was one of the Christians, because the cloth in which the vessel was carried had a picture of the hanged one [șurrat talū̄-i.e., Christ] on it. I surmised that he ate lentils yesterday, since it is the habit of the Christians to eat lentils on Friday. I declared that he was living in such and such a neighborhood because of the red mud that she had at her hem, for in the whole city there is red mud only in this neighborhood." The physician said to him: "Do no longer come before me, for in the art of medicine, which is a noble science, it does not behoove to employ stratagems." ${ }^{28}$

In this interesting episode, the young apprentice is dismissed because he tricked someone into believing that he could deduce information about the patient from the urine, while really coming to his conclusions through other means. It is important to note that the charlatan in question here is not some mountebank in the market, but a pupil training to be a

27. See Ibn al-Nadim, Kitāb al-Fihrist, ed. Gustav Flügel, 2 vols. (Leipzig, 1871-72), 1:

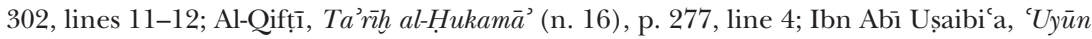
al-anba ' (n. 15), 1: 319, lines 11-14.

28. MS Mh43, fols. 97b, 10 lines from the bottom-98a, line 6; MS Mh280, fol. 49a, 10 lines from the bottom-b, line 3; Steinschneider, "Wissenschaft" (n. 19), p. 578. The translation from Hebrew into English is my own. 
physician. But because he does not conform to the high standards of the art of medicine, in which "it does not behoove to employ stratagems," he is excluded from the medical profession.

Incidentally, this anecdote also tells us something about the social aspects of medical provision. Al-Rāzì does not state explicitly to what religious community the physician and his pupil belonged. From the way they refer to the Christian patient in the text, however, it seems likely that they are non-Christians, and probably Muslims. So, whether or not this story is authentic, al-Rāzī considered it normal that a non-Muslim should seek treatment from a Muslim physician. Later we shall see other examples of interreligious relations within the medical world that suggest a greater degree of competition between physicians of different confessions.

Returning to the deontological aspects of the incident, we see that the physician in this episode is suspicious of uroscopy. Medical techniques could take on special importance for physicians seeking to differentiate themselves from charlatans, who were guilty of imitating physicians not only in dress and general behavior, but also by faking certain medical techniques. Uroscopy provides a good example of this, and it is no accident that al-Rāzì, like the physician in the story, was suspicious of uroscopy-as one can see, for instance, from his short treatise On the Examination and Appointment of Physicians. When examining physicians, he argues, one should not focus too much on their ability to diagnose from urine: "Also, I am of the opinion that an examiner is ignorant who asks the physician to distinguish between human urine and other, similar urine." 29

Al-Rāzì's cautious approach to uroscopy can be compared to similar attitudes in the later Latin Middle Ages. ${ }^{30}$ By 1200, the urine flask had become an attribute by which a physician was instantly recognizable, at least in the popular imagination; hence the many images and illuminations portraying doctors performing uroscopy. However, in learned and university medicine, which developed quite a sophisticated medical theory, inspecting the urine of the patient had become only one among a variety of diagnostic procedures. As Michael R. McVaugh put it: "Empirics might still depend on urine alone for their diagnosis; university-trained physicians

29. Albert Z. Iskandar, ed., "Al-Rāzī wa-mihnnat al-Ṭabīb” (Rhazes and the Examination of the Physician), al-Mašriq, 1960, 54: 471-522, on pp. 502-13; quotation on p. 507, 2 lines from the bottom-last line. Iskandar had previously edited and translated this work in his doctoral thesis ("Study" [n. 26], 1: 395-407 [translation] and 2: 164-76 [text]; here, 1: 401); I have used Iskandar's translation with slight modifications. See also Albert Z. Iskandar, "Galen and Rhazes on Examining Physicians," Bull. Hist. Med., 1962, 36: 362-65.

30. For the following sketch, I rely on Michael R. McVaugh, "Bedside Manners in the Middle Ages," Bull. Hist. Med., 1997, 71: 201-23, on pp. 202-6. 
could boast that their bedside consultations gave them a superior insight into their patients' condition." ${ }^{11}$ Al-Rāzì worried that false practitioners might try, like the pupil in the episode cited, to gain the confidence of their clients through the performance of uroscopy. Like his colleagues practicing in the Latin West some three centuries after him he did not want to overemphasize the importance of this method, because it could easily be imitated by fraudsters. Consequently, without totally dismissing it, he criticized it both in his deontological work on how to examine physicians and in his treatise about why people turn to charlatans.

Al-Rāzī targets not only bad physicians, but also women, who, though not aspiring to become proper physicians, nevertheless represented potentially dangerous competition. When pondering the question of why ignorant physicians and women are so successful, he gives the following explanation toward the end of his treatise, relating how once a woman was credited with a cure that he, himself, had effected:

People are strongly turned away from skilled physicians toward foolish ones, because sometimes ignorant people and women succeed in curing certain illnesses, where wise physicians renowned for their art are unable to do so. There are numerous and manifold reasons for this: luck and opportunity [for instance], which lead to wondrous occurrences. Sometimes, a skillful physician will give a good prescription according to the conduct of the disease, but this is not yet apparent. It also happens that the patient himself sends for a second physician [ rōfe ahêer, probably țabīb ăhar in Arabic] who will attend to his treatment [only] a little. The patient is then cured and this cure attributed to him [i.e., the second physician]. Sometimes the second physician comes to the patient close to the crisis: the terrifying incidents have come to pass, and he [i.e., the second physician] has given him a certain drug. Close to this occur vomiting, diarrhea, sweat, or nosebleed, and the disease ends. People ignorant of the art attribute this to the second physician.

Strange things of this kind have happened to me on many occasions. In one case, I treated someone having suffered for a long time from a stone that was in his bladder, so that there were already signs in the urine, indicating that the stone was disintegrating. It happened that a woman gave the patient a small amount of the drug called 'sfrslym ${ }^{32}$ to drink. He urinated part of the stone, and was relieved from this ailment. People attributed this outcome to the drug, and I was able to explain only to a few intelligent people and those having knowledge of the art that it was the effect of my treatment. The amount of a lentil of 'sfrslym is no more able to crush the stone in the bladder than

31. Ibid., p. 206.

32. Steinschneider, "Wissenschaft" (n. 19), p. 585 n. 1, thinks that this is a corrupt form of Arabic safarğal (quinces). 
smelling it is! I had already for approximately two months given the patient stronger remedies dissolving the stone. ${ }^{33}$

Al-Rāzì is obviously faced with a dilemma. There are certain practitioners in the marketplace-bad doctors and women, as he says-who have the favor of many members of the public. How can one explain this popular success in view of the bad service rendered? The mere fact that al-Rāzī has to grapple with this issue suggests that the competition was fierce. One of his own patients turned to seek treatment elsewhere-a fact that he explains in terms not of his own adequacy, but rather the ignorance of his patient. The viciousness of his assault on women is unmistakable: they are singled out at the beginning of the passage, and a specific female carer is attacked for her incompetence in the second paragraph. Already in the title of the lost treatise Why the Ignorant Physicians, the Common People, and the Women in the Cities Are More Successful . . ., mentioned above, he focused on women as one group of alternative practitioners worthy of his attention; this title thus summarizes three important criteria through which al-Rāzì defines the Other: ignorance in medical matters, low social status, and female gender.

We will encounter these facets of the image of the charlatan again in other contexts, but before turning to different genres of texts, it is useful to highlight one more point in al-Ruhāwī's and al-Rāzī's approach to quackery: Neither of them is content just to warn against charlatans; both call upon the authorities to regulate medical practice (as did Galen in the first quotation discussed in section I above), and both provide concrete guidance on how to examine the physician. ${ }^{34}$ Their concept of what a true physician should know is heavily influenced by Greek models: they take inspiration from Galen's treatise On the Examination of Physicians (De optimo medico cognoscendo) $;^{35}$ moreover, the canon of medical literature that they claim the true physician should know is predominantly Greek. In the next section we shall see how their ideas about empirics and examination are echoed in manuals on market inspection.

33. MS Mh43, fol. 102a, 5 lines from the bottom-b, 11 lines from the bottom; MS Mh280, fols. 53b, line 16-53 bis a, line 10; Steinschneider, "Wissenschaft" (n. 19), pp. 58485. The translation is my own (emphasis added).

34. See notes 22 and 29 above.

35. Albert Z. Iskandar, ed., Galen on Examinations by Which the Best Physicians Are Recognized, Corpus Medicorum Graecorum (henceforth CMG), Supplementum Orientale 4 (Berlin: Akademie Verlag, 1988). For an analysis of the relationship between al-Rāzì's Mihnnat altabīb and Galen's monograph, see Iskandar, "Galen and Rhazes" (n. 29). Vivian Nutton, "The Patient's Choice: A New Treatise by Galen," Class. Quart., n.s., 1990, 40: 236-57, discusses the historical context of Galen's treatise. 


\section{Market Inspection ( hisba)}

As stated in the introduction, there were no guilds of physicians to regulate access to the medical profession in the area and time period considered here. However, there did exist certain institutions associated with the control of health workers, and we have some historical reports concerning how the authorities sometimes tried to control the practice of medicine. The most prominent institution is certainly the office of the inspector of the market (muhtasib), although some scholars have also suggested that doctors were licensed by ǐğazas (permissions), conferred by a master physician upon his pupil. In the following, I will briefly highlight some problems involved in determining what systems were in place to control the provision of health care. However, the main focus will be a physician, al-Šaizarī, who wrote a manual on market inspection in which he specifically deals with the medical and paramedical professions, thereby revealing more facets of the images of legitimate and illegitimate medical practice.

According to Ibn Abī Ușaibi a and al-Qifțī, in the year 931 the caliph al-Muqtadir took dramatic measures when he was informed about some medical malfeasance in Baghdad: he ordered his court physician Sinān ibn Tāait to test all but the best-established medical practitioners in the country, and decreed that only those whom Sinān deemed competent could continue to practice. ${ }^{36}$ Now Ibn Abì Ușaibía and al-Qifțī are not always reliable sources, especially when they describe events that happened three hundred years before their time, but since Ibn Abī Ușaibica quotes this event from the $T a^{3} \bar{r} h$ (History) by Tābit ibn Sinān, the son of Sinān ibn Tābit, it might well be accurate ${ }^{37}$ Be that as it may, such events were not widespread and this action, taken by a specific caliph in the 'Abbāsid capital, was a singular and extraordinary event; it tells us little about the situation in the rural regions, more remote from imperial control, or about other time periods and areas under a different political regime.

36. Ibn Abī Ușaibi'a, 'Uyūn al-anbā' (n. 15), 1: 222, lines 17-23; Al-Qifțī, Ta’rīh alHukamā' (n. 16), pp. 191, line 3-192, line 2. See Ghada Karmi, "State Control of the Physicians in the Middle Ages: An Islamic Model," in The Town and State Physician in Europe from the Middle Ages to the Enlightenment, ed. A. W. Russell, Wolfenbütteler Forschungen, vol. 17 (Wolfenbüttel: Herzog August Bibliothek, 1981), pp. 63-84, on pp. 65-66.

37. See M. S. Khan, "Miskawayh's Use of the Ta'rīkh of Thābit ibn Sinān," Bull. Inst. Islamic Stud. (Aligarh Muslim University), 1962-63, 6-7: 49-57. For a more detailed discussion of this point, as well as al-Muqtadir's special interest in social health-care provisions, see Peter E. Pormann, "Islamic Hospitals in the Time of al-Muqtadir," in Abbasid Studies: Occasional Papers of the School of 'Abbasid Studies, Leuven, 27 June 1-July 2004, ed. J. Nawas et al. (forthcoming). 
It is sometimes alleged that $i \check{g} \bar{a} z a s$, said to be (medical) diplomas, were required in order to work as a physician in the medieval Islamic world. Gary Leiser and Emilie Savage-Smith, among others, have rejected this notion of a universal system of medical diplomas. ${ }^{38}$ It is based on a twofold misconception about i $\check{g} \bar{a} z a s:$ (1) that they constitute licenses to practice; and (2) that they were, if not ubiquitous, at least frequent. Both these assumptions can easily be refuted. An $i \check{g} \bar{a} z a$, literally "permission," is a short text, mostly no more than a paragraph, written by a teacher normally at the end of a religious or legal, but sometimes also a medical, book, confirming that the student has read the work in question. To illustrate the nature of such an i $\check{g} \bar{a} z a$, one can quote, for instance, the famous one written in Ibn al-Nafīs's own hand at the end of his commentary on the Hippocratic treatise On the Nature of Man:

[In the name of] God the Provider of Good Fortune. The wise, learned, and excellent Šaih Šams al-Daula Abū l-Faḍl ibn al-Šaih Abī l-Ḥasan al-Masīhī̄may God make his good fortune long-lasting — studied with me this entire book of mine, that is, the commentary on the book by the master Hippocrates, namely his book known as On the Nature of Man. He [the student] demonstrated the clarity of his intellect and the correctness of his thought-may God grant him benefit and may he make use of it. Certified by the poor in need of God, 'Alī ibn Abī l-Hazm al-Qurašī [known as Ibn al-Nafīs], the physician [mutatabbib]. Praise be to God for his perfection and prayers for the best of His prophets, Muhammad, and his family. [Written] on the twenty-ninth of Ğumādā I [in the] year six hundred and sixty eight [= 25 January $1270 \mathrm{CE}] .{ }^{39}$

This $i \check{g} \bar{a} z a$ - to which, incidentally, Ibn al-Nafiss does not refer as an $i \check{g} \bar{a} z a$ - says little more than that a student studied a text with his teacher, and that he is a capable man. It is not a universal license to practice medicine, nor is it sanctioned by any political or governmental authority.

Second, such $i \check{g} \bar{a} z a$ s are common in hadīt scholarship, but much less so in the world of medicine. ${ }^{40}$ For instance, out of the 216 medical

38. Leiser, "Medical Education" (n. 26), pp. 72-74; Emilie Savage-Smith, Islamic Culture and the Medical Arts: A Brochure to Accompany an Exhibition in Celebration of the 900th Anniversary of the Oldest Arabic Medical Manuscript in the Collections of the National Library of Medicine (Bethesda, Md.: National Library of Medicine, 1994), fols. 13v-14r (no pagination). See also Emilie Savage-Smith, "Islamic Medical Manuscripts at the National Library of Medicine," at http://www.nlm.nih.gov/hmd/arabic/hippocratic.html\#sharh2 (accessed 3 January 2005).

39. National Library of Medicine, MS A69, fol. 67b; this folio is reproduced and translated in Savage-Smith, Islamic Culture (n. 38), fol. 14r (I have used her translation, with slight modifications); it is also found at Emilie Savage-Smith, http://www.nlm.nih.gov/ hmd/arabic/images/a6967b.jpg (accessed 3 January 2005).

40. See Encyclopaedia of Islam, 2nd ed. (henceforth EI), 11 vols. (Leiden: Brill, 19602002), 3: 1020-22, s.v. "idjāza" (G. Varja). 
manuscripts in the fonds arabe of the Bibliothèque Nationale in Paris, only five have $i \check{g} \bar{a} z a$ s, the earliest dating back to 1150 (MS arabe 2874), and the latest to 1614 (MS arabe 3025). ${ }^{41}$ This argument is further supported by the fact that when the Jewish physician Makārim ibn Ishāa petitioned for a position in the Nūr al-Dìn hospital in Cairo around the middle of the thirteenth century, he named two of his teachers to establish his medical credentials, but did not refer to any license or certificate. ${ }^{42}$ Therefore, the $i \check{g} \bar{a} z a$ was not an important means to regulate the medical profession. ${ }^{43}$

Market inspection ( hisba) developed into an important institution in medieval Islamic society. In the formal sense, it first appeared in the ninth century; however, the earliest more comprehensive manuals on this topic date from the eleventh century for the West of the Islamic

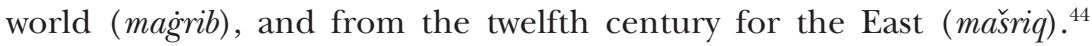
Officials ensured that the weights and measures used in the different souks were correct and that customers would not be cheated. In some of the medieval manuals dealing with market inspection, we also find specific injunctions concerning health workers. Other scholars have described the content of these injunctions, which placed physicians, as well as surgeons, bonesetters, cuppers, ophthalmologists, apothecaries, and perfume-dealers, under the jurisdiction of the muhtasib. ${ }^{45}$ However, the

41. See G. Varja, Les certificats de lecture et de transmission dans les manuscripts arabes de la Bibliothèque Nationale de Paris (Paris: Éditions du Centre National de la Recherche Scientifique, 1957), pp. 37-39; Marie-Geneviève Guesdon, "Manuscrits et histoire de la médecine: Le fonds arabe de la Bibliothèque Nationale à Paris," in Maladies, médecines et sociétés: Approches historiques pour le présent, ed. François-Olivier Touati, 2 vols. (Paris: L'Harmattan et Histoire au Présent, 1993), 1: 36-40.

42. See Donald S. Richards, “A Doctor's Petition for a Salaried Post in Saladin's Hospital,” Soc. Hist. Med., 1992, 5: 297-306, esp. p. 302.

43. The "medical certificate" from the Genizah, T-S NS 327.51-edited, translated, and discussed by Haskell D. Isaacs, "A Medieval Arab Medical Certificate," Med. Hist., 1991, 35: 250-57-is not a license to practice medicine, but rather a document declaring that Abraham the Jew suffers from leprosy and should therefore be limited in his movements; Geoffrey Khan, Arabic Legal and Administrative Documents in the Cambridge Genizah Collections, Cambridge University Library Genizah Series, vol. 10 (Cambridge: Cambridge University Press, 1993), no. 50, pp. 245-46, labels it more appropriately "Testimony concerning a man with leprosy."

44. See EI, 3: 485b-488a, s.v. "hisba" (Claude Cahen and Mohamed Talbi). There is, however, a short treatise on market inspection from the late ninth-century author al-Nāṣir, about whom little else is known: see R. B. Serjeant, "A Zaidī Manual of Hisbah of the 3rd century (H)," Rivista degli Studi Orientali, 1953, 28: 1-34.

45. See Max Meyerhof, "La surveillance des professions médicales et paramédicales chez les Arabes," Bulletin de l'Institut d'Égypte, 1944, 26: 119-34, reprinted in Max Meyerhof, Studies in Medieval Arabic Medicine: Theory and Practice, ed. Penelope Johnstone (London: 
conclusions of these studies are problematic: it is hard to believe that the strict standards in prescriptive manuals were universally imposed throughout the medieval Arabic world. The manuals probably did have some influence on how the muhtasibs went about their business, but it is difficult to ascertain the exact nature of their impact.

Let us leave aside, then, the question of "how medical regulation in medieval Islam really happened" and return to the images of the charlatan, sketched by physicians. The most prominent writer on market inspection is al-Šaizarī, who also had the greatest literary influence on subsequent authors. We have relatively little information about his life, but he flourished during the reign of Saladin (Șalāh al-Dīn, 1169-93) and, in addition to being a judge and physician, he was an accomplished poet. ${ }^{46}$ He wrote a notable book on dream interpretation, ${ }^{47}$ and an interesting and intriguing work entitled The Enlightenment about the Secrets

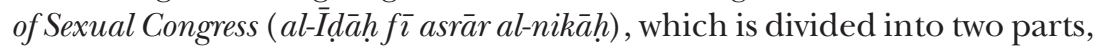
the first being on the secrets of men, and the second on the secrets of women. ${ }^{48}$ His most crucial work, however, is doubtlessly Nihāyat al-rutba fi talab al-hisba (The Utmost Authority in the Pursuit of Market Inspection), upon which Max Meyerhof, Sami Hamarneh, and Ghada Karmi all drew when describing medical market inspection. ${ }^{49}$

Variorum Reprints, 1984), item XI; Sami K. Hamarneh, "Origin and Functions of the Hisbah System in Islam and Its Impact on the Health Professions," Sudhoffs Archiv, 1964, 48: 157-63, reprinted in Sami K. Hamarneh, Health Sciences in Early Islam, ed. Munawar A. Anees, 2 vols. (San Antonio: Noor Health Foundation and Zahra Publications, 1983-84), 1: 113-25; Karmi, "State Control" (n. 36), pp. 69-77.

46. See David Semah, "Rawdat al-Qulüb by al-Šayzarī: A Twelfth-Century Book on Love," Arabica, 1977, 24: 187-206, on pp. 188-91. Al-Šaizarī's poetic opus maius has recently been edited by David Semah and George J. Kanazi, Rawdat al-qulüb wa-nuzhat al-muhibb walmaḥbūb, Codices Arabici Antiqui, vol. 8 (Wiesbaden: Harrassowitz, 2003).

47. Already in 1664, Pierre Vattier translated this treatise from an Arabic manuscript unter the title L'onirocrite mussulman; ou, La doctrine et interpretation des songes selon les Arabes ... De la traduction de P. Vattiez. Sur le manuscrit Arabe (Paris: Billaine, 1664).

48. Muhammad Sa'īd al-Ṭarīhī, ed., The Enlightenment about the Secrets of Sexual Congress (al-Ị̇̂ạh fì asrār al-nikāh) (Beirut: Dār al-Qāri', 1986). The first part contains many recipes for aphrodisiacs, but also chapters on how to enlarge and harden the penis (i. 7) and on contraceptives (i. 9), while the second part is mostly concerned with beauty-enhancing products, but also includes a chapter (ii. 9) on "Knowing drugs that make the vagina narrow, beautiful, and pleasant, and dry its moisture" and another (ii. 10) dealing with charms. Some doubts about the attribution of this work on sexual hygiene to al-Šaizarī have been raised, but they need not be discussed here; see Semah, "Rawdat al-Qulūb" (n. 46), p. 191.

49. Al-Šaizarī, Nihāyat ar-rutba fī țalab al-hisba, ed. al-Sayyid al-Bāz al-'Aqīnī (Cairo: Lağnat al-ta'lif wa-l-tarğama wa-l-Našr, 1946); translated by Ronald P. Buckley, The Book of the Islamic Market Inspector, Supplement 9 to Journal of Semitic Studies (Oxford: Oxford University 
As a physician, al-ŠSaizarī had a natural interest in providing guidelines for the inspection of the market as regards health care. He therefore devoted a number of chapters to medical and paramedical practitioners, the one on "Physicians, Eye Doctors, Bonesetters, and Surgeons" being the most interesting for the present investigation. ${ }^{50}$ Like al-Rāzì and alRuhāwī, al-Šaizarī took the Greeks as a model for his instructions on inspecting physicians. He paints a picture of medical supervision in classical Greek times, where all physicians were obliged to undergo rigorous tests in order to obtain a license to practice medicine. Doctors, al-Saizarī says, were obliged to keep detailed notes on each patient, and, should someone in their care die, a head physician examined the notes and decided whether the practitioner had been negligent and had to pay "blood money [diya]." He concludes his account as follows: "In this admirable manner, the Greek kings took precautions to such an extent that no one could practice medicine who was not a physician, and no physician could be negligent in any medical matter." ${ }^{11}$ This description, to be sure, is more fiction than fact, but it illustrates how a Greek mythical past was used to construe an ideal present. The strict regulations in far-flung Greece were the model for the practice advocated by alSaizarī for the society in which he lived.

Consequently, he set out rules to evaluate the different medical professions: physicians were to be tested in compliance with the guidelines given by Hunain ibn Ishāa in his treatise Mịnnat al-ṭab̄̄b (The Examination of the Physician), ${ }^{52}$ because Galen's work of the same title was too difficult; ophthalmologists were to be examined on the content of $A l^{\mathrm{c}} A \check{s} r$ maqālāt fì l-'ain (Ten Treatises on the Eye) by Hunain ibn Ishạaq; ${ }^{53}$ bonesetters, on the sixth book of Paul of Aegina's Kunnāas (Compendium) $;{ }^{54}$ and surgeons, on Galen's De compositione medicamentorum secundum genera. ${ }^{55}$ This canon for testing the different medical practitioners

Press on behalf of the University of Manchester, 1999). For the studies by Meyerhof, Hamarneh, and Karmi, see n. 45 above.

50. Nihāyat ar-rutba, pp. 97-102; translation, pp. 114-18.

51. Ibid., p. 98, lines 6-9; translation, p. 115 (with slight modifications).

52. This treatise has not come down to us.

53. Hunain ibn Ishāà, The Book of the Ten Treatises on the Eye Ascribed to Hunain ibn Ishāa, ed. Max Meyerhof (Cairo: Government Press, 1928), repr. in Augenheilkunde im Islam: Texte, Studien und Übersetzungen, ed. Fuat Sezgin, 4 vols. (Frankfurt: Institut für Geschichte der arabisch-islamischen Wissenschaften, 1986), 2: 1-516.

54. This is Paul's famous $\pi \rho \alpha \gamma \mu \alpha \tau \varepsilon i ́ \alpha$ (medical handbook), edited by Johan L. Heiberg, CMG, 9.1-2, 2 vols. (Leipzig: Teubner, 1921-24); see Pormann, Oriental Tradition (n. 6).

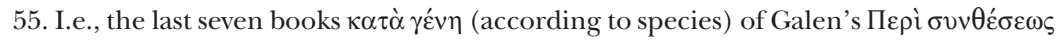

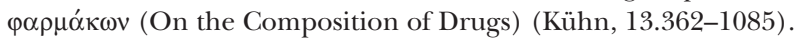


comprises works that were either translated from Greek or based on Greek models. Al-Šaizarī not only defines legitimate medical practice, but also denounces charlatans, warning against stratagems such as substituting cheaper drugs for more expensive ones. The rules he sets out are echoed in other, later treatises on market inspection, and illustrate at least a wish to regulate medical practitioners in the marketplace.

For our argument, it is important to note that physicians who held high office, such as al-Rāzì, warned against charlatans and pressed the political authorities to take steps to ensure that only "legitimate" physicians could practice. For the medical arbiters, legitimate physicians were those who, like them, were well versed in a canon of Greek medical writers such as Galen and Paul of Aegina. With some caution one could generalize these trends, and we might say that the medical establishment was, to a certain extent, successful in dominating the discourse about the supervision of medical professionals; concepts of legitimate practice, which derive their authority from frequent references to all things Greek (whether real or imagined), pervaded what Mohammed Arkoun calls the imaginaire social, the world of ideas that helped to shape a society. ${ }^{56}$ Within these manuals, charlatans are uniformly depicted as outsiders whose activities should be inhibited. To be sure, the images of charlatans discussed so far stem from a literary tradition mostly addressed to the social elite. In the last two parts of this contribution, I shall attempt to shift the perspective somewhat, but first it is useful to highlight two other facets of the charlatan-namely, intercommunal tensions and intraprofessional rivalries.

\section{Jews and Christians as the Medical Other}

A physician called al-Kaskarī, who worked in a number of hospitals in early tenth-century Baghdad, provides us with fascinating insight into his practice through his Compendium (kunnāšs). ${ }^{57}$ Even if it is not possible here fully to explore this rich mine for the social history of medicine, I would like to extract a particularly precious nugget, shedding new light on perceptions of charlatanry-namely, a passage where al-Kaskarī describes how he treated female patients in Kūfa, and denounces the quackery of his Jewish colleagues:

56. Mohammed Arkoun, "Imaginaire social et leaders dans le monde musulman contemporain,” Arabica, 1988, 35: 18-35, on pp. 19-20.

57. See Peter E. Pormann, "Theory and Practice in the Early Hospitals in Baghdad-AlKaškarī On Rabies and Melancholy," Zeitschrift für Geschichte der arabisch-islamischen Wissenschaften, 2003, 15: 197-248. 
In order to make them gain weight during the winter, the women of Küfa are treated by drinking [a variety of] cooked ingredients. They say: "This is duhn [oil]," ${ }^{58}$ because the physicians of Kūfa tell them when administering liquid medicines: "I make you drink duhn in order to make you gain weight by this means,"...

The physicians of the land were mostly Jews, fond of using falsehood and deceit. They used to make castor-oil bean duhn [duhn al-hirwac, an oil made of ricinus communis] with bugloss [šankār] [instead of castor-oil bean]. Once the color of the duhn becomes red, they drip into the decoction these [other] drugs [?]. They said to the women: "This is the Persian duhn." Yet, I disclosed their deceit [in the following way]. I boiled sweet almond duhn together with bugloss. Then the color of the duhn reddened through the presence of the bugloss, and I said to the women: "This is how the Jews are doing it."

There are a number of interesting elements in this quotation. First, we see that the physician is implicitly amused by the fact that women in Küfa use the word $d u h n$, which simply means "oil" in common parlance but is also a technical term for a specific class of compound drugs, in order to refer to any cooked remedy. In other words, these women are ignorant about the subtleties of the medical art and are therefore easily duped. They need the guidance of an experienced physician like al-Kaskarī to protect them from deception.

Second, and more important, al-Kaskarī singles out a specific group of physicians according to their religious affiliation, and declares them collectively to be dishonest. The Jews are "fond of using falsehood and deceit [yuhibbūna sti māla l-kadibi wa-l-gař̌si]": al-Kaskarī sees them as charlatans who dupe gullible women into believing that a remedy actually prepared with bugloss contains castor oil; they fraudulently substitute bugloss for the more expensive castor-oil bean. This adds a new dimension to the definition of the Other. Al-Kaskarī associates the fact that a practitioner is Jewish with his being a fraudster and a quack.

It is impossible, here, to discuss exhaustively Muslim and Christian attitudes toward Jews living in the medieval Islamic world.$^{60}$ However, it is

58. The technical medical term duhn (pl. adhān) designated a specific class of compound remedies, while in common parlance it just meant "oil"; see Sami K. Hamarneh and Glenn Sonnedecker, A Pharmaceutical View of Abulcasis al-Zahrawi in Moorish Spain, with Special Reference to the “Adhan,"Janus Suppléments, no. 5 (Leiden: Brill, 1963).

59. Istanbul, Süleymaniye Kütüphanesi, MS Aya Sofya 3716, fols. 66b, last line-67a, line 2, and 67a, lines 9-14; a facsimile of this MS was published by Fuat Sezgin, Book On Medicine: "Kunnāš" by Ya $a^{c} q \bar{u} b$ al-Kǎskarì, Publications of the Institute for the History of Arabic-Islamic Science, ser. C, vol. 17 (Frankfurt: Institut für Geschichte der arabisch-islamischen Wissenschaften, 1985).

60. The literature on this topic is vast. See, for instance, Bernard Lewis, The Jews of Islam (Princeton: Princeton University Press, 1984), esp. chap. 2, “The Judaeo-Islamic Tradi- 
clear from this passage in al-Kaskarī's Compendium that affiliation with a specific community could become a criterion for accepting or rejecting certain practitioners. Al-Kaskari says: "The physicians of the land were mostly Jews [wa-kāna aṭibbä’ u l-baladi aktaruhum yahūd (sic)], " thus implying that Jewish physicians constitute real competition. There are no precise statistics as to how many physicians belonging to the different communities practiced in the Arabic world at the time. However, Meyerhof has compiled a statistic of the doctors mentioned by the thirteenthcentury Arabic medical historian Ibn Abī Usaibi'a and produced the following results: For the ninth century, Ibn Abī Ușaibi ca lists 130 Christian, 3 Jewish, 3 pagan, and only 5 Muslim physicians; for the tenth century, 29 Christian, 4 pagan, 6 Jewish, and 30 Muslim physicians; and for the eleventh century, 4 Christian, 7 Jewish, and a great majority of Muslim physicians. ${ }^{61}$ We must take these figures with a pinch of salt, not least because Ibn Abī Ușaibi'a’s work contains numerous chronological errors and constitutes not a census of physicians but a work of $a d a b$ (lettres), striving more to entertain than to inform. Yet, even if we allow for a large margin of error, the figures appear to indicate two things: first, that in the ninth and tenth centuries, the majority of physicians were non-Muslim; and second, that al-Kaskarī's claim that most doctors were Jews must be an exaggeration. In at once denouncing Jews as medical frauds and exaggerating their numbers, al-Kaskarī uses religion as a criterion for delimiting himself from other practitioners as well as promoting himself as part of an elite minority of non-Jewish and, by implication, honest physicians.

We will later encounter a case of even greater anti-Jewish resentment, where Jews are portrayed as vicious charlatans. However, a passage from a literary source can further illustrate intercommunal tensions among medical practitioners. Roughly three generations before al-Kaskarī, the renowned Muslim littérateur al-Ǧāḥiz (d. 868/69) recounted an anecdote

tion"; Mark R. Cohen, Under Crescent and Cross: The Jews in the Middle Ages (Princeton: Princeton University Press, 1994). The latter (p. 163) makes the point that Christians were more persecuted by Muslims than were Jews, and that the persecution of Jews by Muslims was "less frequent and less brutal than anti-Jewish persecution in Christendom." More specifically on Jewish physicians in the medieval Islamic world, see Max Meyerhof, "Notes sur quelques médecins juifs égyptiens qui se sont illustrés à l'époque arabe," Isis, 1929, 12: 113-31; Max Meyerhof, "Mediaeval Jewish Physicians in the Near East, from Arabic Sources," Isis, 1938, 28: 432-60. Joseph Shatzmiller, Jews, Medicine, and Medieval Society (Berkeley and Los Angeles: University of California Press, 1994), deals mostly with Jewish physicians in the Latin West after 1250 .

61. Meyerhof, "Notes sur quelques médecins juifs" (n. 60), pp. 116-17. 
in his famous Book of Misers (Kitāb al-Buhalä) that similarly displays sentiments of competition between different religious communities:

He [sc., Asad ibn Ǧānī] was a physician. Once business was slow, so someone said to him: "It is a plague year, disease rampant everywhere, and you are a knowledgeable man with steadfastness, experience, and clear understanding. How does it come about that you have this dearth [of patients]?" To which he replied: "For one thing, people know me to be a Muslim, and have held the belief, even before I began to practice medicine, no indeed even before I was born, that Muslims are not successful in medicine. Then, my name is Asad, when it ought to have been Șalīb, Ğibrāōîl, Yuhannā, and Bīrā [i.e., Christian or Jewish names]. My surname is Abū l-Hāanit, but it ought to have been Abū 'İsā, Abū Zakarìya, and Abū Ibrāhīm [i.e., Christian or Jewish surnames]. I wear a shoulder mantle of white cotton, yet my shoulder mantle ought to be of black silk. My pronunciation is that of an Arab, when my dialect ought to be that of the people of Ğundaisābūr [i.e., of Christian physicians]." ${ }_{62}$

In al-Ǧāhiz̧'s anecdote, the Muslim physician is clearly squeezed out of the market by his non-Muslim colleagues, and he vents his spleen accordingly: they cream off the market, leaving him only a small share. To be sure, Asad ibn Ğānī does not accuse his competition of quackery, but he certainly resents their success. Interestingly, while al-Kaskarī, who was probably a Christian, abuses his Jewish colleagues, seeing them as the Other, this Muslim laments the fact that non-Muslims are perceived to be the better physicians.

Al-Ǧāhiz's account highlights another aspect of defining oneself and the Other, already encountered: the importance of appearance. As we saw earlier, legitimate doctors wore certain clothes and spoke in a specific manner. They were therefore instantly recognizable to potential clients. In his deontological treatise, al-Ruhāwī complained about charlatans imitating the dress and expression of proper physicians. It became a question of "us" and "them": if they imitate us, then we must ensure that this cannot continue. To be sure, Asad ibn Ğānī, the Muslim physician in al-Ǧāhiẓ's anecdote, probably did not try to adopt Christian or Jewish attire or speech-yet dress here appears an integral part of a physician's identity, expressing both his professional and his religious affiliations, and leaving the door open for religion to enter the arena as a criterion for defining insiders and outsiders.

All the accounts examined so far demonstrate the concern of "legitimate" physicians such as al-Ruhāwī and al-Rāzì to guard society from

62. Abū 'Uțmān ibn Baḥr al-Ǧāḥiẓ, The Book of Misers, trans. R. B. Serjeant, rev. Ezzeddin Ibrahim (Reading: Garnet, 1997), p. 86; translation slightly altered. 
what they perceive to be impostors. Their reason for exposing these quacks, as they purport, is to protect the gullible public from swindles and subterfuges. Their altruistic claims should not, however, blind us to other potential motives, such as self-promotion. ${ }^{63}$ Such motives are probably present in the bitter polemic discussed next, which opposed two doctors of different creeds.

\section{Ibn Buṭlān vs. Ibn Riḍwān}

Charlatanism, as stated above, is generally defined as spurious medical practice resulting from dishonesty or incompetence. So far, we have mostly looked at how physicians distinguished themselves from improper medical practitioners using deceit, but we will now turn to the topic of ineptitude. We have already encountered the case of a medical apprentice's being barred from further training because he did not conform to the moral standards set out by his teacher (see section II above). Here we shall see how two fully trained physicians attacked each other viciously because each felt that the other lacked the necessary knowledge to be a legitimate practitioner. In 1049-50, Ibn Buṭlān, a Christian physician practicing in Baghdad (d. after 1063), and Ibn Riḍwān, a Muslim doctor of humble origin based in Cairo (d. ca. 1061), argued in an exchange of epistles about whether "the chicken has warmer nature than a young bird [anna l-farrūğa aharru mina l-farhi] ." ${ }^{64}$ In the second epistle Ibn Riḍwān "accuses IB [Ibn Buțlān] of wrong interpretation . . . , of lies, frauds and lack of logical reasoning," as Meyerhof and Schacht put it. ${ }^{65}$ Ibn Riḍwān denies that Ibn Buṭlān can rightly be called a physician, because he has insufficient philosophical and logical training:

I open this answer with the title given to his [Ibn Buṭān's] treatise [i.e., the previous epistle], for he entitled it "Treatise by al-Muhtār b. al-Hasan b.

63. Cristina Álvarez-Millán has stressed in a different context that self-promotion constitutes an important factor in physicians' motives: see Cristina Álvarez-Millán, "GraecoRoman Case Histories and Their Influence on Medieval Islamic Clinical Accounts," Soc. Hist. Med., 1999, 12: 19-43, on p. 20; Cristina Álvarez-Millán, "Practice versus Theory: Tenth-Century Case Histories from the Islamic Middle East," in The Year 1000: Medical Practice at the End of the First Millennium, ed. Peregrine Horden and Emilie Savage-Smith, Soc. Hist. Med., 2000, 13 (2): 293-306.

64. Max Meyerhof and Joseph Schacht, The Medico-Philosophical Controversy between Ibn Butlan of Baghdad and Ibn Ridwan of Cairo (Cairo: Egyptian University, 1937), p. 70 (trans.), p. 34, line 6 (text). See also Lawrence I. Conrad, "Scholarship and Social Context: A Medical Case from the Eleventh-Century Near East," in Knowledge and the Scholarly Medical Traditions, ed. Don Bates (Cambridge: Cambridge University Press, 1995), pp. 84-100.

65. Meyerhof and Schacht, Medico-Philosophical Controversy (n. 64), p. 16. 


\begin{abstract}
'Abdūn, the Christian physician [țabīb] of Baghdad, about the fact that the chicken is of warmer nature than the young of the bird." However, Galen had explained that the physician $[t a b \bar{\imath} b]$ is [also] an accomplished philosopher, ${ }^{66}$ and that whoever falls short of this is a medical practitioner [ mutatabbīb], not a physician $[t a b \bar{\imath} b]$. Now, the perfect physician is he who has previously obtained knowledge in mathematics, physics, metaphysics, and logic [al- ${ }^{\mathrm{i}} \mathrm{lm}$ al-ta' ${ }^{\mathrm{i}} \overline{\mathrm{i}} \mathrm{m} \bar{\imath}$

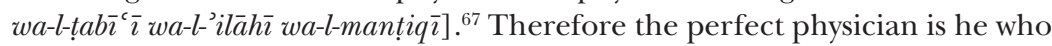
has perfectly obtained each and every one of these things, that is to say, who has reached perfection in them. I credit the sheikh-may God, most high, reform him-with having a share in these things only insofar as he claims [to have them]; what he says in this treatise disgraces him as regards his claim [to be a physician]. We have only heard him lay claim to logic and medicine. Suppose that we grant him logic and medicine, and, in addition to this, natural history, he still could not, by means of these sciences, aspire to be called a physician $[t a b \bar{\imath} b]$. He can only aspire to this if he is granted perfect mastery in all the theoretical and practical branches of science, as Galen explained. Therefore it appears that he committed an error in his title [when referring to himself as "physician" $(t a b \bar{\imath} b)] .{ }^{68}$
\end{abstract}

The attack, leveled with a fair amount of sarcasm, by Ibn Riḍwān against Ibn Buțlān is especially devastating, since the former does not even recognize the latter as a doctor: he verbally excludes him from the medical profession, denying him the right to be called physician (tabīb). By what means and according to what standards does Ibn Riḍān proscribe his opponent? Again, some familiar features emerge. Galen's concept of the physician is the ideal according to which all medical practitioners are judged: "the best physician is also a philosopher," and he should be well versed in the theoretical and practical branches of the art. In order to achieve this, a true physician needs to be schooled according to the basic Greek curriculum of the trivium (grammar, rhetoric, logic) and quadrivium (arithmetic, geometry, music, astronomy), as well as trained in more advanced topics; not having expert knowledge of

66. Galen wrote a small but influential treatise with the programmatic title That the Best

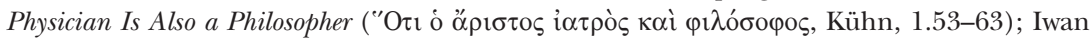
von Müller, Claudii Galeni Pergameni Scripta minora, 3 vols. (Leipzig: Teubner, 1884-93), 2: 1-8. The Arabic translation has been edited by Peter Bachmann, Galens Abhandlung darüber, dass der vorzügliche Arzt Philosoph sein muss, Nachrichten der Akademie der Wissenschaften in Göttingen, Philologisch-Historische Klasse (Göttingen: Vanderhoeck \& Ruprecht, 1965).

67. See Gérard Gehamy, Mawsū'at muștalahāt al-falsafa 'inda l-'arab (Encyclopedia of Arabic Terminology of Philosophy) (Beirut: Librairie du Liban, 1998), entries for math-

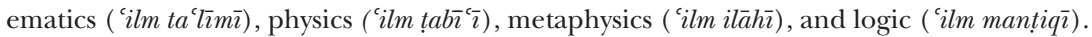

68. Meyerhof and Schacht, Medico-Philosophical Controversy (n. 64), pp. 40, line 8-41, line 2 (text). Meyerhof and Schacht only paraphrase this section of the epistle (p. 77); the translation is my own. 
any of these subjects amounts to not mastering the most basic principles of the art, and thus not being deemed worthy of belonging to the medical profession. The Greek canon, as defined by Galen, is the touchstone of a doctor's ability, but also a handy means to exclude those whom one does not wish to have as one's colleagues. We have observed similar trends in the deontological literature and manuals on market inspection (hisba).

In the previous section, we saw that belonging to a certain community could be constructed as a criterion to define someone as a charlatan. However, in the controversy between Ibn Buțlān, the Christian, and Ibn Riḍān, the Muslim, we find no hint of such religious bigotry: although extremely sharp in his attacks, the Muslim physician does not denigrate the Christian for his impiety, nor does he allege that not belonging to the dominant religion disqualifies him from practicing medicine. This silence about religion is in stark contrast to al-Kaskarī's attitude, as well as that of al-Ğaubarī, whom we shall consider next.

\section{The Reformed Fraudster al-Ǧaubarī}

In the final part of this contribution, we shall turn to two quite different writers, neither of whom was a medical man himself. The first is alĞaubarī, an author known only through his famous Kitāb al-muhtār fī kǎ̃f al-asrār wa-hatk al-astār (The Choicest Part in Disclosing Secrets and Removing Veils), a manual on fraudsters, jugglers, and other confidence artists from different walks of life. ${ }^{69}$ It has attracted the attention of a number of scholars, including Moritz Steinschneider, Michael de Goeje, Heinrich Fleischer, Eilhard Wiedemann, and Stefan Wild.$^{70}$ Biographical

69. This work was printed a number of times in the early twentieth century: see Carl Brockelmann, Geschichte der arabischen Litteratur, Suppl. 1 (Leiden: Brill, 1937), p. 910. I had access only to the Arabic text in Oxford, Christ Church College, MS Arabic 215 (henceforth MS ChA215), and Oxford, Bodleian Library, MS Bodl. Or. 68 (henceforth MS Or68), the latter being a Karshuni manuscript (i.e., Arabic written in Syriac characters).

70. Moritz Steinschneider, "Gauberi's 'entdeckte Geheimnisse': Eine Quelle für orientalische Sittenschilderung," Zeitschrift der Deutschen Morgenländischen Gesellschaft, 1865, 19: 562-77; Michael J. de Goeje, “Ğaubarī's ‘entdeckte Geheimnisse, ” ibid., 1866, 20: 485510; Heinrich L. Fleischer, "Bemerkungen zu Gaubarî’s ‘entdeckten Geheimnissen’ u.a.," ibid., 1867, 21: 274-76; Eilhard Wiedemann, "Über Charlatane bei den Muslimen nach al Gaubarî," Beiträge zur Geschichte der Naturwissenschaften, no. 26, Sitzungsberichte der Physikalisch-Medizinischen Sozietät zu Erlangen, 1911, 43: 206-32, reprinted in Eilhard Wiedemann, Aufsätze zur Arabischen Wissenschaftsgeschichte, 2 vols. (Hildesheim: Olms, 1970), 2: 749-75; Stefan Wild, "Jugglers and Fraudulent Sufis," in Proceedings of the VIth Congress of Arabic and Islamic Studies, Visby 13-16 August, Stockholm 17-19 August, 1972, ed. Frithiof 
information about al-Ğaubarī must be gleaned from within his manual on tricksters, as Wild has suggested..$^{71} \mathrm{Al}$-Ğaubarī was a dervish and alchemist who lived in the first half of the thirteenth century in the Levant and, if he is to be believed, traveled widely. He composed his book between 1232 and 1248, taking inspiration from a work, now lost, called Kašf al-dakk wa-ị̀̂ăh al-šakk (Revealing Fraud and Clarifying Doubts), by the Andalusian poet and littérateur Ibn al-Šuhaid. Al-Ğaubarī's book is divided into thirty sections ( fașls), each containing a variable number of chapters $(b \bar{a} b s)$. The wide range of topics, encompassing fraudulent Sunfīs and false alchemists, reflects many of the activities of the Islamic underworld and the shady creatures, the Banū Sāsān, who inhabit it $;{ }^{72}$ it is therefore a rich mine of information for the social history of medieval Islamic societies. There are a number of sections in this work which specifically deal with medical quackery. Unlike the texts considered until now, this one is not written by a physician, and, as such, it sets out a different view of empirics and constitutes an interesting corrective to the other images of the charlatan. Because of its popular character, the textual tradition of this work is particularly fluid, and subsequent copyists may have lacked the reverence that would have prevented them from altering the original. I shall first discuss the parts devoted to medical charlatans, and then finish with some extracts about Jewish practitioners.

Sections 14 and 15 of al-Ğaubarī's manual, entitled "On the Disclosure of the Secrets of Highway Physicians [atibba al altarīq]" and "On the Disclosure of the Secrets of Those Who Remove Worms from the Molars," respectively, deal specifically with medicine. A typical view of what charlatans are up to, according to al-Ğaubarī, can be found in chapter 7 of section 14, where he describes how a fraudster tricks patients into thinking that he has expelled intestinal worms:

The seventh [chapter, $b \bar{a} b]$ on the disclosure of their secrets.

Another trick is the following. If they want to make a spectacle showing that they administer a drug which expels worms, they take the sinews of camels and give them the shape of the worm. Then they take some laxative

Rundgren, Kungliga Vitterhets historie och antikvitets akademiens handlingar, Filologiskfilosofiska serien, no. 15 (Stockholm: Almqvist \& Wiksell International, 1975), pp. 58-63; Stefan Wild, "A Juggler's Programme in Mediaeval Islam," in La signification du Bas Moyen Âge dans l'histoire et la culture du monde musulman: Actes du 8me Congrès de l'Union européenne des arabisants et islamisants (Aix-en-Provence: Edisud, 1978), pp. 353-60.

71. Most recently in Stefan Wild, "Al-Djawbarī," in EI, Suppl., p. 250. I rely on this article for the following biographical information.

72. See Clifford E. Bosworth, The Mediaeval Islamic Underworld: The Banū Sāsān in Arabic Society and Literature, 2 parts (Leiden: Brill, 1976). 
plant and put these sinews into it without the idiot noticing it. When he eats it, his bowels are moved and nature secretes something which is like water, and in which these sinews similar to worms are present. The patient does not notice anything. Pay attention to this. Know that if I were to explain all that I have insight into, then it would be a long book. But a part of something exemplifies the whole. [The following verses are by sheikh Abū Qāsim alHarīrī:] $]^{73}$

["So if you are quick to seize the drift of words, you will find that all is true and my bloom leads you to guess at my fruit.

"But if you are baffled, then the fault, forsooth, lies with him who knows not how to discern 'twixt sandal and common wood." $]^{74}$

There are two typical features of how al-Ğaubarī depicts the empiric that are significant here. First, he goes into some detail when explaining the stratagem in question. Second, there is no reference whatsoever to Greek or Galenic medicine. Al-Ğaubarī is interested only in the fraud, and not in the medical training or knowledge of the person who performs it.

As a second example, it is interesting to quote chapter 3 of section 15, because it describes a trick similar to that performed in the account of Galen's exposing a quack. In each case, people are made to believe that the charlatan can extract worms from their teeth, but there are some notable differences between Galen's account and that by al-Ğaubarī; the latter runs as follows:

The third chapter $[b \bar{a} b]$ about their secrets.

Another trick is the following. They take camel sinews and divide them so that they are the size of worms while they are fresh. Then they cut them with scissors into small worms. Then they dry them. Once they are dry, they mix them into pills. If they want the worm to come out of the tooth, they take a little bit of this pill and leave it on the tooth. When the sinew becomes warm [in the mouth], they open it. Then it comes out, and nobody doubts that it is a worm, and that they [the charlatans] have extracted it from the tooth. Pay attention to this. ${ }^{75}$

The two typical features of the first example also emerge in this second one: al-Ğaubarī describes the minutiae of the stratagem, while at the same time not showing any concern for Greek medical theory.

73. The verses are taken from maqāma 44 of The Assemblies of Al Harîri, trans. Thomas Chenery and Francis J. Steingass, 2 vols. (London, 1867), 2: 139; text: Silvestre de Sacy, ed., Les séances de Hariri, 2nd ed. (Paris: Imprimerie royale, 1847-52), 2: 589, last line-590, line 1. The text in square brackets is not contained in MS ChA215.

74. MS ChA215, fol. 99b, line 3, my translation. MS Or68, fols. 98b, line 1-99a, line 11, contains only the beginning of section 14 followed by three recipes, and could therefore not be collated.

75. MS ChA215, fol. 107a, lines 9-61. Chaps. 2 and 3 are inverted in MS ChA215. 
Al-Ğaubarī's approach can be compared to that displayed in the anecdote about Galen. According to Ibn Abī Ușaibi a and al-Qifțī, Galen does not explain exactly how the mountebank puts the worm into the mouth of his victim; he merely states that the charlatan took it from a box [h̆uqq]. Even greater vagueness can be found in al-Rāzì's Kitāb al-Manșūrī; when listing the different tricks to which quacks resort, al-Rāzì only remarks: "Some conceal in the ears or in the root of the teeth worms generated in cheese, and later undertake to get them out."

The mountebank in Ibn Abī Ușaibi a's's and al-Qifțî̀s account pretends to have studied with Galen in order to appear more knowledgeable and legitimate, and Galen calls into question his ability to cup. By contrast, in al-Ğaubarī there is no reference to Galenic medical theory, and no discussion of incompetence as opposed to immorality; he is just concerned with disclosing and describing intentionally deceitful tricks.

The difference between al-Ǧaubarī's approach and that of the physicians reviewed so far can easily be explained. Al-Ǧaubarī, as is apparent from his book, has firsthand experience with the frauds that he now denounces, and he is not shy to admit it; by contrast, physicians such as al-Rāzì did not want to appear to be too familiar with the ruses and subterfuges of quacks, lest they appear overly well-versed in the techniques of guile and so raise suspicions about their practice. Moreover, alRāzì and other physicians belonging to the medical elite had recourse to a Greek canon of theoretical works when defining who is and is not a physician. Al-Ğaubarī's perspective, on the other hand, is at variance with that of the medical elite: his writing is both derived from and, to a lesser extent, aimed at the market and its denizens. Whatever Greek medical theory might have trickled down to the popular imagination-and certain concepts such as humoral pathology certainly became commonplace-al-Gaubari is concerned with practical performance and not theory. However, in at least one area, attitudes toward Jews, his ideas are similar to those of an elite physician, al-Kaskarī.

Al-Ğaubarī devotes a whole section to Jews: section 5, "On the Disclosure of the Secrets of the Jews and What They Do" (Fī kašfi asrāri l-Yahūdi $w a-m \bar{a}$ yacmalūna). Part of this specifically deals with Jews as medical charlatans, and in it he is particularly harsh, even by his own standards. This is illustrated by the beginning of the first chapter of the section:

Know that this group [i.e., the Jews] is the most execrable of all creation and the most fraudulent, godless, and cursed. They are the most heretic in their

76. The text and translation of the Kitāb al-Manșūrì are in Iskandar, "Study" (n. 26): trans. (slightly modified), 1: 365; text, 2: 155, last line-156, line 2. 
deeds, and their baseness and vileness is most apparent. If they are alone with someone, they kill him, and mix into his food a soporific drug. So pay attention to this and be wise. ${ }^{77}$

In chapter 2 of the same section al-Ğaubarī describes how Jewish physicians would kill off their patients if asked to by an interested heir. The Jewish physician is depicted as a particularly perfidious artist: if a wife wants her husband dead, the Jew first extorts money from her and offers to fulfill her request. But his wickedness does not stop there, as alĞaubarī purports:

If she is pretty and he desires her, he leaves her on that day, but later [returns and] says: "Know that this matter can only be concluded through having sexual intercourse with you, so that I can prepare for him [i.e., the husband] a drug made of the sperm. Then the task will be finished." He does not leave her alone until she agrees to this.

Look at this cleverness, cunning, and guile, and how they trick people out of their money, corrupt their wives, and take away their innermost possessions. Pay attention to this. ${ }^{78}$

This picture that al-Ǧaubarī paints of Jewish practitioners-and he does not mince words-is, to be sure, a prejudiced caricature. Although similar to al-Kaskarī in some aspects, the tone and tenor are much more aggressive and hostile in al-Ğaubarī. Can al-Ğaubarī's utterances be interpreted as indicative of popular resentment against Jews, or of intercommunity strife, rife in the circles he frequented? Whatever the answer to this question, elite medical literature in general seems to be more moderate in tone when it comes to relations between Muslims, Christians, and Jews.

77. MS ChA215, fol. 46a, line 2, my translation. The text has previously been edited by Steinschneider, "Gauberi's 'entdeckte Geheimnisse" (n. 70), p. 573, from Berlin, Staatsbibliothek, MS We. 1656 (5563 Ahlwardt) and MS Or68; his text is quite different from that contained in MS ChA215 (on which the present translation is based), but the general thrust is the same. See also Moritz Steinschneider, Polemische und apologetische Literatur in arabischer Sprache zwischen Muslimen, Christen und Juden, Abhandlungen zur Kunde des Morgenlandes, vol. 6.3 (Leipzig, 1878), app. II, pp. 188-91.

78. MS ChA215, fol. 47a, line 6; the text edited by Steinschneider, "Gauberi's 'entdeckte Geheimnisse'” (n. 70), p. 575, lines 6-10, although quite different in expression and style, has the same content. 


\section{Literary Depictions and Manuscript Illumination of the Mountebank in Al-Harīrī's Maqāmāt}

The last source to be discussed is another author who is not a physician. Al-Harīrī (d. 1122) wrote the famous Maqāmāt-literally, "standings," meaning instances of someone standing up to recite rhymed prose or poetry, as opposed to mağàlis (sessions, séances), where ordinary prose is recited; ${ }^{79}$ for tradition's sake, I shall refer to them here as "assemblies." Al-Harīrī's Maqāmāt belong to a genre in which entertaining anecdotes are recounted in rhymed prose $\left(\check{s} a \breve{g}^{c}\right)$ intermingled with poetry. They have their origin in popular storytelling, but in al-Harīrī's case they attained a high level of linguistic and stylistic sophistication. One of his "assemblies" depicts a scene involving cupping, which is highly amusing and extremely revealing of how charlatans were represented in works of fiction. Moreover, since many manuscripts of the Maqāmāt are richly illuminated, they permit us literally to look at the image of the charlatan-an image that is at odds with the portrait painted by the physicians discussed earlier, as we shall see.

In each of the fifty "assemblies" in al-Harīrī's masterpiece, the narrator, named Hārit ibn Hammām, encounters the protagonist, called Abū Zaid al-Sarūğ̄in, who is often in the company of his son. In each case, Abū Zaid is surrounded by a throng of people admiring his latest performance of scams and stratagems, by which he endeavors to rid them of their money. The story of the forty-seventh assembly involves cupping and unfolds according to the same pattern. Hārit ibn Hammām wants to be cupped and sends his slave to find him a cupper. The slave returns without having persuaded anybody to come to his master's house. After some deliberation, Hārit ibn Hammām decides to look for a cupper himself. He finds a sheikh with a boy surrounded by rows and rows of onlookers. The sheikh refuses to cup the boy unless he is paid in advance. An argument ensues in which the boy claims to be poor, yet of high extraction and willing to pay later; the cupper understandably rejects this reasoning, as he is uncertain of retrieving his fee if the boy should abscond. They come to blows and the boy's sleeve is torn; the youth complains bitterly, and the sheikh apologizes. The discussion continues: the boy rebuffs the cupper's apologies, while the latter refuses to pay for the mending of the sleeve. Then the boy begs the audience for money in order to overcome his misfortune. A large sum is collected, and

79. Alfred F. L. Beeston, "Al-Hamadhān̄̄, al-Harīrī and the maqūmāt genre," in 'Abbasid Belles-Lettres, ed. Julia Ashtiany et al. (Cambridge: Cambridge University Press, 1990), pp. 125-35, on p. 127; in what follows, I draw heavily on this contribution. 
later the two divide it equally. When they begin to depart together, Hārit ibn Hammām requests that the sheikh cup him. The latter then asks whether the former is not amazed by his cunning. Hārit ibn Hammām realizes that the cupper is none other than Abū Zaid, who used this charade to line his pockets. The plot of this "assembly" may seem trivial and unsophisticated; however, the real entertainment is provided by the highly stylized expression, the juxtaposition of vulgar and literary language, and the extremely refined poetry interwoven into the tale.

Whatever the stylistic merits of this "assembly" may be, it portrays Abū Zaid as a charlatan who poses as a cupper and, by faking an argument with a customer who is actually in cahoots with him, manages to inspire pity in the crowd and defraud them of their money. The trick consists not so much in pretending to have medical skills that he does not possess, but in tricking the onlookers into giving alms through a phony fight with his boy, who seems to be in dire straights as a result.

It should also be noted that Abū Zaid is depicted as an incompetent cupper in his shop in numerous illuminations found in Maqāmāt manuscripts. ${ }^{80}$ For instance, in an illumination in a St. Petersburg manuscript, onlookers surround a shop front that contains shelves laden with utensils. In the center, Abū Zaid is depicted cupping the back of his son. He employs a vessel resembling two others on the lower shelf just above the boy, which look like a cup with a straight spout or handle; Abū Zaid uses this handle to hold the vessel that he applies to the boy's back. ${ }^{81}$

Previous scholarship has often assumed that this and other illustrations of this assembly are actual depictions of how cupping was performed in the market. ${ }^{82}$ Emilie Savage-Smith, however, has argued that this assumption is most likely erroneous for a number of reasons. ${ }^{83}$ The utensils displayed on the shelves of the shop in both illuminations belong to a perfume-dealer ( ${ }^{c} a t \underline{t} \bar{a} r$ ) rather than a cupper (hăğğàm). The vessels with a spout on the lower shelf in the manuscript are inappropriate for cupping; actual cupping vessels did not have a spout or any other handle, as we can see from al-Zahrāwī (d. shortly after 1009), a medical author

80. Oleg Grabar, The Illustrations of the Maqamat, Studies in Medieval Manuscript Illumination, Chicago Visual Library Text-fiche no. 45 (Chicago: University of Chicago Press, 1984), pp. 98-100.

81. St. Petersburg, Institute of Oriental Studies, MS C 23, fol. 165a.

82. See Emilie Savage-Smith, "A Medical, Pharmaceutical or Perfumery Utensil," in Francis Maddison and Emilie Savage-Smith, Science, Tools and Magic, Nasser D. Khalili Collection of Islamic Art, no. 12, 2 vols. (London: Nour Foundation, 1997), 1: 42-47, on p. 46 n. 13.

83. Ibid., pp. 42-43. 
who described many instruments in great detail in his medical encyclopedia called The Book: The Arrangements [of Medical Knowledge] for One Who Is Unable to Compile [a Manual for Himself] (Kitāb al-Tașrīf li-man 'ağiza 'an alta $(\bar{l} f) .{ }^{84}$ Moreover, in al-Harīiñ's story, Abū Zaid's son asked to be cupped at the nape of the neck (not on the back, as in the illumination), which is a less-typical place for cupping. Finally, cuppers normally practiced their art in bathhouses (hammäms), and not in shops.

The Maqāmāt are satires: they show how the mountebank Abū Zaid fleeces bystanders out of their money; naturally, they are meant to be funny. Accepting the above arguments, one can interpret the scene presented as follows. The charlatan Abū Zaid has not a clue as to how to cup someone: he uses the wrong utensils in the wrong surroundings and on the wrong part of the body, the back. His mistakes were instantly recognizable to the book's readers, for cupping was quite a common practice, and therefore the whole scene seems utterly ridiculous. The story illustrates that images can work only if the public has a notion of correct practice. The joke is effected by something departing from the norm, by Abū Zaid's making a pig's ear of cupping his son..$^{85}$

Moreover, the Maqāmāt share certain features with al-Ǧaubarī's work on tricksters. In the present "assembly," references to Galenic medicine or any other Greek authorities are completely absent. Al-Ǧaubarī's warning against charlatans can be taken as an indication that alternative practitioners were active in the marketplace. Likewise, the anecdote from the Maqāmāt shows that, despite the efforts of physicians to distinguish themselves from charlatans and to limit the influence and market share of the latter, potential customers were attracted by a good spectacle

84. A facsimile was published by Fuat Sezgin, "A Presentation to Would-Be Authors" On Medicine, Publications of the Institute for the History of Arabic-Islamic Science, ser. C, vols. 31.1-2 (Frankfurt: Institute for the History of Arabic-Islamic Science, 1986). See also Martin S. Spink and Geoffrey L. Lewis, eds., Albucasis On Surgery and Instruments: A Definitive Edition of the Arabic Text with English Translation and Commentary (Berkeley and Los Angeles: Wellcome Institute of the History of Medicine, 1973). The apothecary-turned-Arabist John Channing had already edited part 30 of the Tașriff, dealing with surgery, in 1778; for more information about this interesting orientalist see Emilie Savage-Smith, "John Channing: Eighteenth-Century Apothecary and Arabist," Pharm. Hist., 1988, 30: 61-116. See also Emilie Savage-Smith, "Al-Zahrāwī," in EI, 11: 398-99.

85. Willem M. H. Hummelen, "Doubtful Images,” Theatre Res. Internat., 1997, 22: 20218 , when discussing images of charlatans in sixteenth- and seventeenth-century illustrations and paintings, encounters a similar problem of interpretation: sometimes the pictures represent real-life charlatans, but at other times they show "charlatan farces"- that is to say, they are representations of a caricature, as is the case in the manuscript illuminations of Maqūmāt. 
and would react to methods of persuasion not favored by the medical establishment.

\section{Conclusions}

We have just seen how a variety of authors writing medical handbooks, deontological treatises, theoretical epistles, and manuals for market inspection, as well as a reformed trickster and a prestigious littérateur, depicted the Other-the quack, empiric, charlatan, mountebank. In most cases, these writers were warning their readers against quacks, and took great care to establish the difference between "them" and "us." Even in the case of the Maqāmāt with their beautiful illustrations, the moral, at least on one level, appears to be that those going to the market should beware of mountebanks such as Abū Zaid.

Moreover, the physicians were not content with just warning against quacks. Like their Greek predecessors, they called on the political authorities to regulate their profession by giving precise instructions for the vetting of physicians. Their demands did not fall on entirely deaf ears: in the manuals of market inspection, the standards laid down by medical authors were used to test different practitioners in the marketplace. The theoretical injunctions thus served to establish a dominant discourse of who was a legitimate physician, surgeon, ophthalmologist, and so forth. And doctors did not stop at warning against fraudulent behavior and laying down rules in order to stamp it out: they vilified their colleagues on the grounds that the latter did not fulfill the high standards required by Galen and the ancients. They thus had recourse to a canon of texts in order to demarcate themselves as legitimate physicians from the others, who were deficient in their knowledge of the pertinent canonical works.

Tension between different communities and sexes also played a part in the description of the Other. It is clear from al-Ǧăhiz’s description that Christian and Jewish physicians dominated the medical scene in the ninth century; his account is corroborated by the statistics gleaned from Ibn Abī Ușaibi'a's history of physicians. At the beginning of the tenth century, al-Kaskarī could still claim that most of the physicians of the land were Jews, although this was probably an exaggeration. Al-Ǧāhịiz’s account makes it clear that a Muslim physician could feel rancor against Jews and Christians for taking away his potential clients. Likewise, alKaskarī ranted and raved against his Jewish colleagues, purportedly in order to warn against them, but likely also because they were potential competitors. Al-Ğaubarī, the reformed mountebank, raged against Jews even more fiercely than al-Kaskarī; it is difficult to see why he is so violent in his attacks, and he seems to express some of the more pervasive and 
stereotypical anti-Jewish sentiments. ${ }^{86}$ Be that as it may, all these authors show that allegiance to a specific community could serve as a criterion to exclude the Other.

Women form another group of people singled out by physicians. AlRāzì complained that women were credited with successfully treating patients while he himself-at least if we are to believe his own accountwas really responsible for effecting the cure. Al-Kaskari displayed a patronizing attitude toward women, whom he perceived to be gullible and ignorant. It is a fair surmise to say that women, whether as midwives, healers, or carers, catered to the medical needs of a substantial part of the community, and were therefore in competition with male practitioners-which could account for al-Rāzì's prejudices. However, it is difficult to make general assertions about women in medical and paramedical professions in the period and region discussed here, owing to the dearth of research on the topic; female practitioners in the classical period of Islam seem to be one of the blind spots of scholarly attention..$^{87}$ In the absence of more sophisticated research, suffice it here to point out that gender was important when physicians demarcated themselves from alternative practitioners.

The images of the charlatan in the texts discussed here have certain common features, despite all the individual differences-namely, deliberate deception and incompetence. The physicians mentioned in this study, who all belonged to the medical and social elite, endeavored to eradicate the perceived improbity and imbecility of their potential competitors by denigrating them and calling upon the political authorities to regulate and censor them. However, the very fact that medical authors throughout the ages, and more specifically during the period under

86. Literature on the subject of anti-Semitism is legion; I cite just one recent publication that can serve as a starting point for further reading: Marvin Perry and Frederick M. Schweitzer, Antisemitism: Myth and Hate from Antiquity to the Present (New York: Palgrave Macmillan, 2002).

87. There are, to be sure, some scholarly publications on women and their role in society and literature, or women as child-carers. To cite just a few recent contributions: Jonathan P. Berkey, "Women in Medieval Islamic Society," in Women in Medieval Western European Culture, ed. Linda E. Mitchell (New York: Garland, 1999), pp. 95-111; Therisa Rogers, "The Islamic Ethics of Abortion in the Traditional Islamic Sources," Muslim World, 1999, 89: 122-29; Avner Giladi, "Gender Differences in Child Rearing and Education: Some Preliminary Observations with Reference to Medieval Muslim Thought," Al-Qantara, 1995, 16: 291-308; Avner Giladi, Infants, Parents and Wet Nurses: Medieval Islamic Views on Breastfeeding and Their Social Implications (Leiden: Brill, 1999); Nadia Maria El-Cheikh, "Women's History: A Study of al-Tanūkhī," in Writing the Feminine: Women in Arab Sources, ed. M. Marín and R. Deguilhem (London: Tauris, 2002), pp. 129-48. 
scrutiny here, complained relentlessly about charlatans is a potent testimony to the fact that these alternative practitioners continued to offer their services to the community and could not be totally excluded from the marketplace. In the Maqāmāt, we see Abū Zaid surrounded by a large crowd despite his obvious incompetence in the art of cupping: he is depicted as incapable as well as immoral, but still hugely popular. Such images illustrate that the medical elite never wholly succeeded in excluding the reviled Other, the mountebank, the charlatan. 